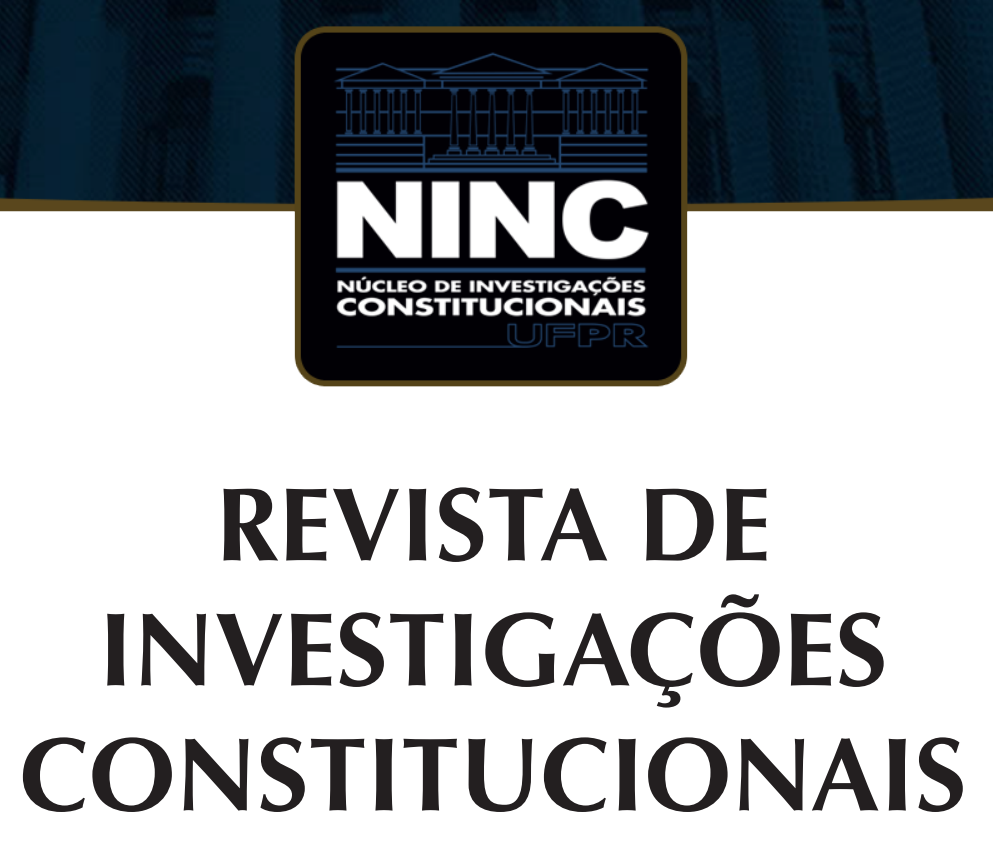

JOURNAL OF CONSTITUTIONAL RESEARCH

vol. 8 | n. 1 | janeiro/abril 2021 | ISSN 2359-5639 | Periodicidade quadrimestral Curitiba | Núcleo de Investigações Constitucionais da UFPR | www.ninc.com.br 


\title{
Anti-convencionalidade: erros, incoerências e paradoxos de um instrumento de controle sem controle
}

\section{Anti-conventionality: errors, inconsistencies, and paradoxes of a control instrument without control}

\author{
LUCAS CATIB DE LAURENTIIS ${ }^{1, *}$ \\ ' Pontifícia Universidade Católica de Campinas (Campinas, São Paulo, Brasil) \\ lucas.laurentiis@gmail.com \\ https://orcid.org/0000-0001-5596-6695
}

FELIPE GRIZOTTO FERREIRA 1 ,**

' Pontifícia Universidade Católica de Campinas (Campinas, São Paulo, Brasil)

felipe.g.ferreira@hotmail.com https://orcid.org/0000-0002-4204-8569

Recebido/Received: 17.02 .2020 / February $17^{\text {th }}, 2020$ Aprovado/Approved: 12.12.2020/ December 12 $2^{\text {th }}, 2020$

Resumo

A partir de 2006, juristas e autoridades latino-americanas têm se deparado com um novo desafio no âmbito do exercício do poder para invalidação de leis e atos normativos: o controle de convencionalidade. Embora a literatura majoritária tenha recepcionado de maneira

\section{Abstract}

Since 2006, Latin American lawyers and authorities have faced a new challenge in the exercise of power to invalidate laws and normative acts: the control of conventionality. Although the majority literature has received this innovation extremely positively, there are several inconsistencies and

Como citar esse artigo/How to cite this article: LAURENTIIS, Lucas Catib de; FERREIRA, Felipe Grizotto. Anti-convencionalidade: erros, incoerências e paradoxos de um instrumento de controle sem controle. Revista de Investigações Constitucionais, Curitiba, vol. 8, n. 1, p. 237-274, jan./abr. 2021. DOI: 10.5380/rinc.v8i1.71780.

" Professor Titular Categoria A1 da Pontifícia Universidade Católica de Campinas (Campinas-SP, Brasil). Coordenador e membro do corpo docente permanente do Programa de Pós-Graduação stricto sensu em Direito (PPGD), vinculado à linha de pesquisa "Cooperação Internacional e Direitos Humanos". Mestre e Doutor em Direito constitucional pela Faculdade de Direito da Universidade de São Paulo. Foi pesquisador visitante com bolsa CAPES sanduíche da Albert Ludwigs Universität Freiburg e do Instituto Max Planck de Freiburg. É especialista em Direito constitucional pela Pontifícia Universidade Católica de São Paulo. Foi professor nos cursos de especialização e pós-graduação da Pontifícia Universidade Católica de São Paulo. Foi professor e orientador da Escola de Formação da Sociedade Brasileira de Direito Público. Foi pesquisador e professor convidado da Fundação Escola de Sociologia e Política de São Paulo e Membro da comissão de Direito constitucional da OAB-SP. É advogado e consultor nas áreas de direito público e direito tributário. E-mail: lucas.laurentiis@gmail.com.

** Mestre em Direitos Humanos e Desenvolvimento Social pela Pontifícia Universidade Católica de Campinas (Campinas-SP, Brasil). Graduado em Direito pela PUC-Campinas, com período sanduíche na Universidade de Coimbra. E-mail: felipe.g.ferreira@ hotmail.com. 
extremamente positiva essa inovação, existem diversas incoerências e inconsistências desse instrumento. É o que este trabalho busca demonstrar e problematizar. Com base em um método descritivo e normativo, será demonstrado que tal instrumento de controle carece de fundamento. Isso gera problemas conceituais, pois não existe possibilidade de aplicar uma sanção normativa através do juízo de convencionalidade, o que afasta a ideia de controle normativo. A adoção desse instrumento também gera sérios problemas procedimentais e de competência sancionatória nos ordenamentos jurídicos dos Estados. Por fim, a identificação de decisões ativistas da Corte interamericana consiste em mais um fator contrário ao controle de convencionalidade.

Palavras-chave: direito internacional; direito comparado; controle de convencionalidade; Corte Interamericana de Direitos Humanos; crítica. inconsistencies of this instrument. This is what this paper seeks to demonstrate and problematize. Based on a descriptive and normative method, it will be demonstrated that such a control instrument is unfounded. This generates conceptual problems, since there is no possibility of applying a normative sanction through the judgment of convention, which removes the idea of normative control. The adoption of this instrument also creates serious procedural and sanctioning problems in the legal systems of States. Finally, identifying the activist decisions of the Inter-American Court is one more factor contrary to the control of conventionality.

Keywords: International Law; Comparative Law; control of conventionality; Inter-American Court of Human Rights; criticism.

\section{SUMÁRIO}

1. Introdução; 2. Controle sem fundamento; 3. Controle sem controle; 4. Controle sem procedimento; 5. Conclusões; 6 . Referências.

\section{INTRODUÇÃO}

"Nossos braços, então, alcançam o céu", disse o Ministro Eros Grau em julgamento que debatia a possibilidade de decisões do Supremo Tribunal Federal serem afastadas por norma do poder Legislativo que recria a lei declarada inconstitucional.' Não haveria, para o Ministro, órgão superior ou visão mais qualificada do que a apresentada pela Suprema corte brasileira quando a questão debatida é a validade da lei que afronta parâmetros constitucionais. $O$ céu do Supremo é a prevalência de seu ponto de vista, mesmo que ele afronte a decisão de um órgão representativo. Mesmo que não exista consenso argumentativo acerca dos resultados do julgamento. Hoje o Supremo Tribunal Federal não está mais só em sua cruzada pela ascensão celeste. Ele encontrou um competidor a sua altura: a Corte Interamericana de Direitos Humanos (CIDH). Impulsionada pelo movimento de globalização e pela consequente multiplicação de órgãos internacionais incumbidos de apreciar violações a parâmetros internacionais de direitos humanos, ${ }^{2}$ a CIDH trilhou um caminho ambicioso e inovador em seus julgamentos. Criou uma jurisprudência que, com boas razões, já foi denominada de "criativa",

Rcl. 4335, rel. Min. Gilmar Mendes, j. 20 de março de 2014.

2 Apresentando as causas desse movimento: TUSHNET, Mark. The inevitable globalization of Constitutional Law. Virginia Journal of International Law, [s.l.], vol. 50, p. 985-1004, 2009, p. 992. De forma similar: BOGDANDY, Armin von. Demokratie, Globalisierung, Zukunft des Völkerrechtes - eine Bestandaufnahme. ZaöRV, [s.I.], vol. 63, p. 853-877, 2003. p. 854. 
"avant-garde" e até "legalmente não conformista". ${ }^{3}$ Quando dois órgãos jurisdicionais com ideias criativas e formas de julgar não conformistas se chocam, dois podem ser os resultados. Ou surgirá um novo direito, um novo futuro, uma nova forma de pensar; ${ }^{4}$ ou ocorrerá a desconstrução e dissolução de tudo o que há de estável e certo no direito.

Em matéria de controle da validade de atos normativos, a inovação vinda da jurisprudência da Corte interamericana é o controle de convencionalidade das leis e atos normativos internos. ${ }^{5}$ Concebida à imagem e semelhança do conceito de controle de constitucionalidade, ${ }^{6}$ tal figura tem pouco mais de dez anos de existência e seus efeitos já são sérios a ponto de se ter se afirmado que sua criação representou uma virada copernicana na compreensão do direito, pois gerou um verdadeiro Big bang na jurisprudência constitucional e interamericana. ${ }^{7}$ Surgiu uma euforia convencional. Citada como a chave para a solução de controvérsias envolvendo a atualização de pressupostos do direito penal, ${ }^{8}$ direito processual penal, ${ }^{9}$ direito administrativo, ${ }^{10}$ direito do trabalho, ${ }^{11}$ processo civil, ${ }^{12}$ direito eleitoral, ${ }^{13}$ a justiça de transição, ${ }^{14}$ a convencionalidade se tor-

3 HENNEBEL, Ludovic. The Inter-American Court of Human Rights: the Ambassador of Universalism. Quebec Journal of International Law, Quebec, n. 57, special edition, p. 57-97, 2011. p. 59.

4 Uma defesa radical dessa concepção foi defendida em BARROSO, Luís Roberto. Contramajoritário, representativo e iluminista: os papeis dos tribunais constitucionais nas democracias contemporâneas. Direito e Praxis, Rio de Janeiro, vol. 9, n. 4, p. 2171-2228, 2018, para quem compete aos tribunais constitucionais "acender a luz na escuridão, submeter a vontade à razão".

5 A esse respeito, ver o trabalho recente de ROCHA, Matheus Lins; FERREIRA, Olavo A.; TARREGA, Maria Cristina. O controle de convencionalidade difuso de ofício e a vedação das decisões-surpresa. Espaço Jurídico Journal of Law, Joaçaba, vol. 20, n. 2, p. 317-336, jul./dez. 2019.

6 Para um quadro comparativo entre essas modalidades de controle, ver: GARCIA RAMIREZ, Sergio. El control judicial interno de convencionalidad. Revista IUS, Puebla, vol. 5, n. 28, 2011. p. 123-159.

7 BURGORGUE-LARSEN, Laurence. Chronicle of a Fashionable Theory in Latin America: Decoding the Doctrinal Discourse on Conventionality Control. In: HAECK Yves; HERRERA, Clara Burbano; CHIRIBOGA, Oswaldo Ruiz (Org.). The Inter-American Court of Human Rights: Theory and Practice, Present and Future. Cambridge: Intersentia, 2016. p. 637.

8 GOMES, Eduardo Bianchi; GONÇALVES, Ane Elise. O controle de convencionalidade, a Convenção Americana de Direitos Humanos e o crime de desacato, Revista Jurídica da Presidência, [s.l.], vol. 18, n. 114, p. 73-96.

9 FEITOSA, Gustavo Raposo; SILVA NETO, Ademar Monteiro. Audiência de custódia, convenções internacionais de direitos humanos e liberdade de locomoção. NOMOS - Revista do Programa de Pós-Graduação em Direito da UFC, Fortaleza, vol. 36, n. 2, p. 153-170, 2016.

10 ALIANAK, Rachel Cynthia. El renovado derecho administrativo a la luz del control de convencionalidad. Revista latinoamericana de derecho administrativo, [s.I.], vol. 2, n. 1, p. 283-299, 2015.

11 BELTRAMELLI NETO, Silvio; KLUGE, Cesar Henrique. Controle de convencionalidade difuso e concentrado em matéria trabalhista nas perspectivas da OIT e do Sistema interamericano de proteção dos direitos humanos. Revista direito e justiça - reflexões sóciojurídicas, Santo Ângelo, ano XVII, n. 28, p. 105-123, 2017.

12 TALAMINI, Eduardo. O exame de sentenças da jurisdição brasileira pela Corte Interamericana de Direitos Humanos. Cadernos da Escola de Direito e Relações Internacionais da Unibrasil, [s.l.], vol. 06, p. 205-229, 2006.

13 FERREIRA, Marcelo Ramos Peregrino. O controle de convencionalidade da Lei da Ficha Limpa: direitos políticos e inelegibilidades, Rio de Janeiro: Lumen Juris, 2015.

14 ROTHENBURG, Walter Claudius. Constitucionalidade e convencionalidade da Lei de Anistia Brasileira. Revista de Direito GV, São Paulo, vol. 9, n. 2, p. 681-705, 2016. 
nou o elemento de intersecção, e conflito, dos direitos constitucional e internacional dos direitos humanos. ${ }^{15}$

Não há mais espaço imune à influência da convencionalidade e esse conceito foi alçado ao patamar antes ocupado por outras figuras do direito público sobre as quais se deposita a esperança de se construir um novo direito, um novo futuro, uma nova era, em que as fronteiras entre as ordens jurídicas nacionais e internacionais sejam apagadas. Os perigos e problemas dessa cruzada iluminista não são novos e suas causas são conhecidas: o ganho de influência do direito internacional e a diluição das fronteiras nacionais se revelaram, muitas vezes, ${ }^{16}$ como puros pretextos para a expansão do poder político de nações desenvolvidas, ${ }^{17}$ assim como a proteção internacional dos direitos humanos se revelou, algumas vezes, como uma forma velada de proteção da livre circulação de bens e mercadorias e da garantia de segurança para a acumulação do capital. ${ }^{18} \mathrm{O}$ controle de convencionalidade é mais um ingrediente desse caldo de ideias, sentimentos e expectativas em que se transformaram o direito internacional público e o direito internacional dos direitos humanos.

Assim, se as instituições e relações internacionais e sua sistemática normativa podem ser utilizadas para manutenção da desigualdade de distribuição de poderes entre os Estados e até mesmo para o desencadeamento de uma fragilização dos princípios democráticos, um pensamento crítico e responsável se faz necessário frente a essas novas tendências. Apresentamos aqui algumas dúvidas a respeito de tal possibilidade. A noção de inconvencionalidade, ao nosso ver, sofre de deficiências de fundamentação que no limite comprometem a aplicação da jurisprudência convencional que a sustenta (item II). Fora isso, o próprio conceito de controle de inconvencionalidade é equivocado, pois não há similitude entre os pressupostos e o funcionamento do sistema de controle de constitucionalidade das leis e as características da inconvencionalidade (item III). Pensamos também que tal qual concebido e fundamentado, o controle de convencionalidade não pode ser nem mesmo utilizado pela Suprema corte constitucional brasileira, o que gera um paradoxo no interior da sistemática de controle brasileira (item IV). Esse é o caminho e essas são as conclusões deste estudo. Não são conclusões fáceis, não só porque a literatura nacional tende a louvar a inconvencionalidade, escondendo

15 PIOVESAN, Flávia. Direitos humanos e diálogo entre jurisdições. Revista Brasileira de Estudos Constitucionais, São Paulo, n. 19, p. 67-93, 2012.

16 Nessa linha e questionando os critérios que levam o Conselho de segurança da ONU a autorizar intervenções territoriais: MURSWIEK, Dietrich. Souveränität und Humanitäre intervention. Der Staat, [s.l.], vol. 35, n. 1, p. 31-44, 1996.

17 Para uma visão altamente crítica dessa situação, ver: KOSKENNIEMI, Martti. International Law as Political Theology: How to Read Nomos der Erde?. Constellation, [s.l.], vol. 11, n. 4, p. 492-511, 2004.

18 Observando que o direito internacional dos direitos humanos passou a ser utilizado na defesa de investidores internacionais perante tribunais arbitrais: TORRIJO, Ximena Fuentes. International and Domestic Law: Definitely an Odd Couple. University of Puerto Rico Law Review-Seminar in Latin America on Constitutional and Political Theory (SELA), [s.I.], vol. 77, n. 2, p. 483-505, 2008. 
seus problemas, mas também porque a crítica da inconvencionalidade e da jurisprudência da Corte interamericana de direitos humanos pode ser muito facilmente confundida como uma crítica aos direitos humanos e aos valores que eles representam. Por isso, são raros os estudos que apresentam uma visão crítica a esse respeito. ${ }^{19}$ Frente a essa possível crítica não há muito o que fazer senão lamentar pela partidarização do debate jurídico e lembrar que a crítica sincera e tenaz é, na verdade, o maior elogio que se pode fazer ao autor, ao valor ou à noção criticados.

\section{CONTROLE SEM FUNDAMENTO}

Competência é delimitação de poder. ${ }^{20}$ Em uma organização estatal, o poder é exercido de duas formas distintas: ou pela criação de normas cogentes ou pela eliminação dessas mesmas normas. A competência pode, assim, ser definida em termos positivos - para o caso de se autorizar a criação de normas - ou negativos - quando se abre a possibilidade de um determinado órgão eliminar leis ou atos normativos integrantes do sistema jurídico. ${ }^{21} \mathrm{Em}$ ambos os casos, por se tratar de uma parcela de competência, exige-se sempre que o ato de criação ou eliminação normativos sejam amparados em uma regra de competência explícita, que lhes dê fundamento e legitimidade. Se é assim, o exercício de uma competência negativa, que se realiza com a anulação de normas jurídicas, deve ter uma fundamentação explícita e precisa. Caso contrário não se estará perante um caso de exercício legítimo de competência e sim diante de um ato de usurpação de poder.

É exatamente por isso que a criação teórica e jurisprudencial do controle de convencionalidade foi seguida pela busca incessante de seu fundamento normativo. Sem ele, afinal, essa espécie de controle não passaria de um ato ilegítimo de apropriação de poder. Foram, então, empreendidos os mais diversos esforços na busca do elo perdido da fundamentação do controle de convencionalidade. Nessa tarefa inglória, três foram os principais candidatos a tábua de salvação dessa forma não convencional

19 Entre as exceções encontradas na literatura nacional, ver: MARTINS, Leonardo; MOREIRA, Thiago Oliveira. Controle de convencionalidade de atos do poder público - concorrência ou hierarquia em face do controle de constitucionalidade?. In: PAGLIARINI, Alexandre Coutinho; DIMOULIS, Dimitri (Coord.). Direito constitucional internacional dos direitos humanos. Belo Horizonte: Fórum, 2012, p. 301, onde se afirma que não cabe à Corte internacional "revogar a lei inconvencional ou regrar abstratamente a situação levada a julgamento, substituindo o legislador estatal".

20 Sobre o conceito de competência, ver na literatura processual: CARNEIRO, Athos Gusmão. Jurisdição e competência, São Paulo: Revista dos Tribunais, 2005. p. 67; DINAMARCO, Cândido Rangel. Instituições de processo civil: volume 1. 5. ed. São Paulo: Malheiros, 2005. p. 436, onde se diz que a competência é o"conjunto de atribuições de cada órgão ou conjunto de órgãos, estabelecidas pela Constituição ou pela lei".

21 A equivalência em termos normativos, dos atos de criar e anular regras jurídicas, foi assim constatada por Hans Kelsen: "anular uma lei é estabelecer uma norma geral, porque a anulação de uma lei tem o mesmo caráter de generalidade de sua elaboração, nada mais sendo, por assim dizer, que a elaboração com sinal negativo" (KELSEN, Hans. Jurisdição constitucional. São Paulo: Martins Fontes, 2003. p. 152). 
de controle. Primeiro, afirmou-se que o controle de convencionalidade seria uma derivação direta do que dispõem os artigos $1^{\circ}$ e $2^{\circ}$ do Pacto de San Jose da Costa Rica..$^{22}$ Depois sustentou-se que o princípio internacional do pacta sunt servanda e a Convenção de Viena formariam em conjunto a base do controle de convencionalidade. ${ }^{23}$ Por fim, houve quem apelou para o direito francês, onde uma decisão da década de setenta do Conselho constitucional indicaria a existência dessa nova forma de controle de validade das leis. ${ }^{24}$ Nenhuma dessas tentativas convence.

A primeira delas desconsidera o próprio texto da Convenção americana, que no artigo $2^{\circ}$ exige que os "Estados-partes" adotem as medidas necessárias a garantir os direitos e liberdades nela previstos "de acordo com as normas constitucionais" de cada Estado. Se este texto e seus termos têm algum sentido, eles querem dizer que o sujeito a quem é endereçado a obrigação de adequar as normas internas às internacionais é o próprio Estado, não a $\mathrm{CIDH}$, que, ao criar o controle de convencionalidade, chama essa tarefa para si e, com isso, altera um pacto internacional sem que as partes signatárias estejam necessariamente de acordo com essa modificação. Quem agride, portanto, a boa-fé dos acordos internacionais e a ideia do pacta sunt servanda é, neste ponto, a própria CIDH ao criar o controle de convencionalidade. ${ }^{25}$ Na verdade, o texto da Convenção

22 Dentre muitos outros, nesse sentido: CAVALLO, Gonzalo Aguilar. El control de convencionalidad: análisis en derecho comparado. Revista Direito GV, São Paulo, n. 18, p. 721-754, jul./dez. 2013. p. 726 e ss.; HITTERS, Juan Carlos. Control de constitucionalidad y control de convencionalidad: comparación. Estudios Constitucionales, Talca, vol. 7, n. 2, p. 109-128, 2009; ALCALÁ, Humberto Nogueira. Los desafíos del control de convencionalidad del corpus iuris interamericano para los trinunales nacionales y su diferenciación con el control de constitucionalidad. In: MARINONI, Luiz Guilherme; MAZZUOLI, Valério de Oliveira (Coord.). Controle de convencionalidade: um panorama latino-americano. Brasília: Gazeta Jurídica, 2013. p. 474; MAC-GREGOR, Eduardo Ferrer. Interpretación conforme y control difuso de convencionalidad: el nuevo paradigma para el juez mexicano. Estudios Constitucionales, Talca, vol. 9, n. 2, p. 531-622, 2011. p. 533; MAGALHÃES, Breno B. O controle difuso de convencionalidade no Brasil: soluções para seu aprimoramento. In: CHAl, Cássius Guimarães; BUSSINGUER, Elda Coelho de Azevedo; CHAVES, Valena Jacob (Org.). Ensaios críticos: do político ao jurídico. 1. ed. Campos dos Goytacazes: Brasil Multicultural, 2016. p. 107.

23 Os dispositivos de tal Convenção obrigam as partes a cumprir os acordos internacionais com boa-fé e impedem que uma delas invoque o direito interno para justificar o descumprimento de um tratado. Buscando justificar o controle de convencionalidade com esses argumentos, dentre muitos outros autores nacionais: CAMILO, Guilherme Vitor de Gonzaga. A aplicação dos tratados e a doutrina do controle de convencionalidade: bases jurídicas e efetivação. Revista de direito brasileira, São Paulo, vol. 17, n. 7, p. 18-39, maio/ago. 2017. p. 25; CARVALHO, Alexander Perazo Nunes de. Convencionalização do direito civil: a aplicação dos tratados e convenções internacionais no âmbito das relações privadas, Revista de direito internacional, Brasília, vol. 12, n. 2, p. 341-354, 2015. p. 351.

24 Nessa linha, que se tornou particularmente popular no direito brasileiro: MAZZUOLI, Valerio de Oliveira. $\mathbf{O}$ controle jurisdicional da convencionalidade das leis. 2. ed. São Paulo: Revista dos Tribunais, 2011. p. 81; RUSSOWSKY, Iris Saraiva. O controle de convencionalidade das leis: uma análise na esfera internacional e interna. Revista CAAP, Belo Horizonte, vol. XVIII, n. 2, p. 61-96. p. 64; CHAVES, Denilsson Gonçalves; SOUSA, Mônica Teresa Costa. O controle de convencionalidade e a autoanálise do poder judiciário brasileiro. Revista da Faculdade de Direito - UFPR, Curitiba, vol. 61, n. 1, p. 87-113, jan./abr. 2016.

25 Com as mesmas observações e conclusões: BILDER, Christina. The prohibition of amnesties by the inter-American Court of Human Rights, German law journal, [s.I.], vol. 12, n. 5, p. 1203-1230, 2011, p. 1216; CONTESSE, Jorge. The Final Word? Constitutional Dialogue and the Inter-American Court of Human Rights. I-CON, [s.l.], vol. 15, n. 2, p. 414-435, 2017. p. 419. 
não diz aqui nada além do óbvio: enquanto signatários de um acordo internacional, compete a cada Estado cumprir o que foi acordado. E, se este compromisso não foi cumprido, será possivelmente o caso de se impor uma sanção internacional. Mas isso não quer dizer que se atribuiu à $\mathrm{CIDH}$ a competência para invalidar as normas estatais que estejam em desacordo com o direito internacional. Muito menos quer dizer que a manifestação desta Corte crie automaticamente as condições práticas para a implementação de todo um sistema de controle normativo. Pelas mesmas razoes, não tem sentido contornar este problema, sustentando que a Convenção americana também atribui à $\mathrm{CIDH}$ a competência de "determinar que se assegure ao prejudicado o gozo do seu direito ou liberdade violados". ${ }^{26}$ Determinar não significa anular e, a bem da verdade, uma Corte que detenha o poder de declarar a nulidade de leis ou atos normativos, disso retirando as consequências práticas dessa declaração, não precisa de nenhuma determinação adicional para ver seus julgados cumpridos. Não é esse o caso da Corte interamericana de direitos humanos, que por isso mesmo não detém competência de controle e não foi autorizada pelo tratado que a criou a exercer essa atividade. Tudo isso quer simplesmente dizer que, se não existe em um determinado país as condições que tornam possível a adequação do direito interno ao compromisso internacional, a CIDH não pode exigir que essas condições sejam criadas em um passe de mágica. ${ }^{27}$

Ocorre que a condição mais elementar de existência do controle de convencionalidade é a sobreposição das normas integrantes do tratado internacional de proteção de direitos humanos a toda e qualquer norma interna estatal. Sem que isso ocorra, sempre será possível que o fundamento da declaração de inconvencionalidade seja, ele mesmo, inválido, em decorrência de um eventual vício de inconstitucionalidade. ${ }^{28} \mathrm{Se}$ esta condição não existe, podem ocorrer três situações: ou a convenção se sobrepõe às leis internas, mas está submetida às normas constitucionais; ou leis e convenções estarão em um mesmo nível de hierarquia normativo; ou as convenções têm o mesmo nível

26 É o que dispõe no artigo 63 da Convenção americana. Em sentido contrário, afirmando que "no sistema interamericano, a previsão de que a sentença da Corte assegurará, o quanto possível o direito exercício (sic) do direito violado presta-se a indicar, entre outras consequências, a desnecessidade de um mecanismo interno de invalidação da sentença nacional": TALAMINI, Eduardo. O exame de sentenças da jurisdição brasileira pela Corte Interamericana de Direitos Humanos. Cadernos da Escola de Direito e Relações Internacionais da Unibrasil, [s.l.], vol. 06, p. 205-229, 2006. p. 220.

27 Estranhamente a própria Corte interamericana reconheceu esse fato ao afirmar que "embora a Corte reconheça a importância desses órgãos como protetores dos mandatos constitucionais e dos direitos fundamentais, a Convenção Americana não impõe um modelo específico para realizar um controle de constitucionalidade e de convencionalidade" (Liakat ali Alibux vs. Suriname, setença de 20 de janeiro de 2014, parágrafo 124). Se isso é certo, como foi aqui observado, não tem sentido a noção de inconvencionalidade. Apontando essa contradição: JUÁREZ, Karlos A. Castilla. Control de convencionalidade interamericano: una mera aplicación del derecho internacional. Revista Derecho del Estado, n. 33, p. 149-172, jul./dez. 2014. p. 159.

28 É sintomático que Néstor Sagüés, um dos maiores defensores do controle de convencionalidade, seja também um dos poucos que reconhecem esse fato, afirmando ainda que este é o "calcanhar de Aquiles" deste instrumento de controle: SAGÜÉS, Nestor Pedro. Obrigaciones internacionales y control de convencionalidade. Estudios Constitucionales, Talca, vol. 8, n. 1, p. 117-136, 2010, p. 124. 
normativo das normas constitucionais. ${ }^{29}$ No terceiro caso a criação de um novo instrumento de controle é desnecessária: bastará o controle de constitucionalidade para resguardar a autoridade tanto da Constituição quanto dos tratados internacionais de direitos humanos. No segundo caso não há condição para se falar em qualquer espécie de controle com base em disposições de tratados internacionais, pois assim como as leis os tratados serão objeto, não parâmetro de controle. Mas e na primeira hipótese? Apesar de boa parte da literatura afirmar que a posição intermediária dos tratados internacionais autorizaria a realização do controle de convencionalidade, ${ }^{30}$ a verdade é outra. Isso pelo simples fato de que, se tanto o tratado quanto a lei estão submetidos à Constituição, o critério de prevalência das normas internas ou internacionais será uma decorrência da interpretação do parâmetro constitucional, não do próprio tratado. Se a existência da violação do tratado depende da aferição do critério constitucional que determina a precedência desta norma, não há um verdadeiro controle de convencionalidade, mas sim uma aferição reflexa e indireta da constitucionalidade. É exatamente a mesma situação que ocorre quando se trata da determinação da incidência de normas federais ou estaduais. Em casos de conflitos entre essas espécies normativas, deve-se recorrer ao critério constitucional que determina a precedência das normas criadas pelos diversos entes federativos. ${ }^{31}$ Assim como nessa hipótese não ocorre necessariamente a invalidação de uma norma que adentre na competência de outro ente federado, sobretudo quando se tem em conta as normas de divisão de competências no plano vertical, no caso do conflito entre normas nacionais e internacionais a Constituição pode determinar a prevalência de qualquer destas normas, sem que ocorra a invalidação ou a anulação de nenhuma delas. ${ }^{32}$

\footnotetext{
29 Já é antigo o entendimento que defende a equiparação da hierarquia de tratados internacionais e normas constitucionais no direito brasileiro. Sua defesa pode ser encontrada em: PIOVESAN, Flávia. Direitos humanos e o Direito constitucional internacional. São Paulo: Saraiva, 2008. p. 72. Contudo, essa interpretação não subsiste mais no direito brasileiro depois da aprovação da Emenda constitucional n. 45/2004, que explicitamente exige que os tratados internacionais de direitos humanos sejam aprovados por quórum de aprovação de emendas constitucionais para que sua hierarquia seja equivalente à Constituição.

30 Afirmando que a supralegalidade seria condição suficiente para o exercício do controle de convencionalidade: RAMOS, André Carvalho. Supremo Tribunal Federal brasileiro e o controle de convencionalidade: levando a sério os tratados de direitos humanos. Revista da Faculdade de Direito da Universidade de São Paulo, São Paulo, vol. 104, p. 241-286, jan./dez. 2009. p. 259; MARINONI, Luiz Guilherme. Controle de convencionalidade (na perspectiva do direito brasileiro). In: MARINONI, Luiz Guilherme; MAZZUOLI, Valério de Oliveira (Coord.). Controle de convencionalidade: um panorama latino-americano. Brasília: Gazeta Jurídica, 2013.

31 Acerca de tais critérios, ver o estudo clássico de: ALMEIDA, Fernanda Dias Menezes de. Competências na Constituição de 1988. 4. ed. São Paulo: Atlas, 2007.

32 Direto e preciso neste sentido: REIMER, Philipp. "L'état, c'est le droit" - sobre a atualidade da teoria do Estado de Hans Kelsen em face da metamorfose do poder estatal. Cadernos do programa de pós-graduação em Direito UFRGS, Porto alegre, vol. XI, n. 1, p. 50-79, 2016. p. 65.
} 
Não é de todo impossível que uma ordem constitucional reconheça a superioridade de normas internacionais em relação às disposições da Constituição, ${ }^{33}$ caso em que se estará transferindo a função de organização final do poder de um estado para uma instância internacional. Neste caso, seria possível cogitar de um controle de convencionalidade até mesmo de normas constitucionais. Mas essa não é uma regra geral do direito internacional e comparado; muito menos é o que ocorre no direito brasileiro. Em todo caso, uma transferência de competência decisória como essa não pode ser pressuposta por ilações argumentativas ou argumentações doutrinárias. Ela precisa estar prevista claramente, sob pena de se caracterizar não só como uma modificação unilateral da decisão estatal que levou à assinatura e à incorporação do tratado internacional, mas também como uma usurpação da opção democrática que indica a última instância decisória de um país. Deve-se observar, assim, que a determinação do nível hierárquico de qualquer espécie normativa - incluso os tratados - é uma variável que deve ser determinada de forma democrática e transparente por cada país. ${ }^{34}$ Não há uma regra universal e necessária a esse respeito e, por isso, não se pode pressupor, como faz a $\mathrm{CIDH}$ que o confronto entre normas internas e internacionais sempre deve ser resolvido em favor dessas. ${ }^{35}$ Essa conclusão que deve ser comprovada e não afirmada peremptoriamente.

33 Sustentando que os tratados internacionais de proteção de direitos humanos têm prevalência sobre as normas internas, inclusive as constitucionais: MELLO, Celso D. de Albuquerque. Curso de direito internacional público. 15. ed. Rio de Janeiro: Renovar, 2004. p. 839. No direito comparado, o caso mais conhecido e citado de Estado que admite a superioridade de regras de direito internacional em relação às normas constitucionais é a Holanda, tal que se afirma em: MAZZUOLI, Valério de Oliveira. Hierarquia constitucional e incorporação automática dos tratados internacionais de proteção dos direitos humanos no ordenamento brasileiro. Revista de informação legislativa, [s.l.], ano 37, n. 138, p. 231- 250, out./dez., 2000. p. 237, afirmação essa que não está totalmente de acordo com a realidade, pois a Constituição holandesa condiciona a prevalência das normas internacionais em relação aos parâmetros constitucionais à aprovação do tratado por maioria qualificada de dois terços dos membros do congresso. E como esse é o mesmo quórum exigido para a modificação do texto constitucional holandês, entende-se que essa votação implica a mudança do parâmetro constitucional, que passa então a incorporar o texto do tratado em seu corpo. Nesse sentido: ANDO, Nisuke. National implementation and interpretation. In: SHELTON, Dinah (Org.). The Oxford Handbook of International Human Rights Law, Oxford: Oxford University Press, 2013. p. 698.

34 Neste exato sentido: ALMEIDA, Fernanda Dias Menezes de. A incorporação dos tratados internacionais ao ordenamento jurídico brasileiro: análise do tema à luz do direito constitucional. Revista do Advogado, São Paulo, ano 23, n. 73, p. 48-58, 2003. A mesma regra é válida para o continente Europeu como se observa em: LÜBBE-WOLFF, Gertrude. ECtHR and national jurisdiction - The Görgülü Case. Humboldt Forum Recht, n. 12, p. 138-146, 2006. p. 139, onde se afirma que a Convenção europeia não indica o "mecanismo por meio do qual os Estados membros e seus órgãos observarão a Convenção"; MÜCKL, Stefan. Kooperation oder Konfrontation? Das Verhältnis zwischen Bundesverfassungsgericht und Europäischem Gerichtshot für Menchenrechte. Der Staat, [s.l.], vol. 44, n. 3, p. 403-431, 2005. p. 407, onde também se observa que os tratados internacionais, sejam eles de direitos humanos ou não, têm hierarquia legal na Alemanha.

35 No mesmo sentido, o próprio Hans Kelsen, que é considerado um dos defensores da visão monista, afirmou com base na jurisprudência da Corte internacional de justiça, que: "The question as to whether in case of a conflict between national and international law the one or the other prevails can be decided only on the basis of the national law concerned; the answer cannot be deduced from the relation which is assumed to exist between international and national law" (KELSEN, Hans. Principles of International Law. New York: Rinehart and Co., 1952. p. 419). 
O recurso à Convenção de Viena sobre direito dos tratados leva a problemas similares, ${ }^{36}$ mas esse caminho tem alguns agravantes. Quem fundamenta o controle de convencionalidade neste tratado se vale da seguinte disposição: "Uma parte não pode invocar as disposições de seu direito interno para justificar o inadimplemento de um tratado". ${ }^{37}$ Essa linha argumentativa não vai muito longe. Primeiro porque este dispositivo não diz muito mais do que o óbvio: é evidente que, ao ratificar um tratado internacional, os Estados devem se abster de alegar impedimentos decorrentes de sua legislação interna. Caso contrário nenhum acordo internacional terá valor, pois sempre será possível aprovar uma norma que exclua essa obrigação. Isso quer simplesmente dizer que, seja lá qual for a razão que leve um estado a descumprir uma obrigação internacional, esse ato sempre gera a responsabilidade do Estado infrator. ${ }^{38}$ Daí a se concluir que os tratados internacionais se transformaram em parâmetro de invalidação de normas internas há uma distância brutal.

Segundo porque a Convenção de Viena não cria nenhuma hierarquia normativa especial para os tratados. Ela simplesmente diz que eles devem ser cumpridos, sem explicitar qual a consequência do seu descumprimento. ${ }^{39}$ Consta inclusive dos anais dos trabalhos preparatórios desta Convenção a proposta de Luxemburgo, que pretendia incluir um dispositivo no texto no qual se atribuía prioridade às normas internacionais quando em confronto com regras locais. Se esta proposta tivesse sido aprovada, haveria fundamento textual na Convenção de Viena para a implantação do controle de convencionalidade. Não foi isso o que ocorreu. ${ }^{40}$ Afirmar, portanto, que essa Convenção exige que normas internas sejam anuladas com base em parâmetros internacionais, é uma inferência criada pela Corte interamericana de direitos humanos, não uma

36 Dita Convenção foi incorporada ao direito brasileiro pelo Decreto presidencial 7.030/2009.

37 Dentre muitos outros, sustentando que o citado artigo da Convenção de Viena (art. 27) fundamenta o controle de convencionalidade: BAZÁN, Victor. El control de convencionalidade: incógnitas, desafios y perspectiva, In: BAZÁN, Victor, NASH, Claudio (Org.). Justicia constitucional y derechos fundamentales: el control de convencionalidad, Berlim: Konrad Adenauer Stiftung, 2011. p. 24. A própria Corte interamericana de direitos humanos se refere a ese argumento no julgamento do conhecido caso Almonacid arrellano, afirmando que "esta Corte estabeleceu que, '[s]egundo o Direito Internacional, as obrigações por este impostas devem ser cumpridas de boa-fé e o Direito Interno não pode ser invocado para justificar seu descumprimento'. Esta regra foi codificada no artigo 27 da Convenção de Viena sobre o Direito dos Tratados de 1969" (sentença de 26 de setembro de 2006, C-154, parágrafo 125)

38 A mesma conclusão pode ser retirada do art. 32 do Draft Articles on Responsibility of States for Internationally Wrongful Acts, segundo o qual: "The responsible State may not rely on the provisions of its internal law as justification for failure to comply with its obligations under this part".

39 Nessa linha, afirmando que a Convenção de Viena se refere à responsabilidade internacional dos Estados, "não à maneira de incorporação dos tratados ou à sua hierarquia no direito interno": DULITZKY, Ariel. An Inter-American Constitutional Court? The Invention of the Conventionality Control by the Inter-American Court of Human Rights. Texas International Law Journal, Texas, vol. 50, n. 1, p. 47-93, 2015. p. 63.

40 Com as mesmas conclusões a respeito dos trabalhos preparatórios da Convenção: TORRIJO, Ximena Fuentes. International and Domestic Law: Definitely an Odd Couple. University of Puerto Rico Law Review-Seminar in Latin America on Constitutional and Political Theory (SELA), [s.I.], vol. 77, n. 2, p. 483-505, 2008. p. 489-491. 
imposição do texto. Enfim, ainda de acordo com o texto da Convenção de Viena, os direitos e as obrigações deste tratado se dirigem a regular os tratados firmados entre Estados. ${ }^{41}$ Não se sabe, por isso, como e por que uma Corte internacional, no caso a $\mathrm{CIDH}$, que não é um Estado, poder utilizar esse tratado para criar uma obrigação que nem mesmo está prevista em seu texto. Ocorre aqui, portanto, uma argumentação circular e altamente paradoxal: o controle de convencionalidade busca fundamentação na Convenção de Viena, que não prevê dessa espécie de controle e, por isso, é violada pela criação deste instrumento de controle.

Finalmente, há a inferência do controle de convencionalidade com fundamento em decisões do Conselho constitucional francês. Quanto a esse ponto, é preciso questionar por que, afinal, a utilização de uma técnica de controle em solo francês deve levar à sua implantação no continente americano? Aqui é preciso recordar que instrumentos legais de ordens normativas estrangeiras não podem ser importados sem que o país ou organismo receptor esteja em condições para receber essa transposição. Mais do que isso, deve-se lembrar que o estudo teórico do direito comparado não gera efeitos normativos e, por isso, a pesquisa e descrição de um instrumento de controle do direito estrangeiro não tem nenhum efeito sobre outros sistemas jurídicos. ${ }^{42} \mathrm{Com}$ essas premissas em mente, o contexto em que o Conselho constitucional francês criou o seu modelo de controle de convencionalidade deve ser esclarecido para então se concluir se e em quais condições o instrumento criado por esta Corte pode ser transportado para a América.

Quando, na década de setenta, o Conselho se negou a aferir a compatibilidade de um projeto de lei que descriminalizava a prática do abordo em relação a tratados internacionais, os pressupostos mais simples desta decisão foram: a Constituição francesa de 1958 tem um dispositivo que explicitamente atribui nível supralegal a tratados internacionais. ${ }^{43}$ Fora isso, no direito francês anterior à reforma de 2008, não havia nenhuma possibilidade de se contestar a constitucionalidade de uma lei depois de sua promulgação. ${ }^{44}$ Isso dá sentido ao entendimento do Conselho que no citado julgamento se nega a aferir a adequação do projeto de lei em relação ao tratado, juízo esse que

41 É o que diz a Convenção de Viena em seu art. 10: "A presente Convenção aplica-se aos tratados entre Estados".

42 Como bem observa José Afonso da Silva, o direito comparado não é um "ramo do direito" como os demais, pois "não se pode falar de direito comparado objetivo, porque não existe um conjunto de normas de direito comparado" (SILVA, José Afonso. Um pouco de direito constitucional comparado. São Paulo: Malheiros, 2009. p. 31.

43 Trata-se do conhecido artigo 55 da Constituição de 1958, segundo o qual: “Les traités ou accords régulièrement ratifiés ou approuvés ont, dès leur publication, une autorité supérieure à celle des lois, sous réserve, pour chaque accord ou traité, de son application par l'autre partie".

44 A respeito da implantação do procedimento de controle repressivo e concentrado no direito constitucional francês, ver: FABBRINI, Federico. Kelsen in Paris: France's Constitutional Reform and the introduction of a posteriori constitutional review of legislation. German Law Journal, [s.I.], vol. 9, n. 10, p. 1297- 1312. 2008. 
não deve de forma alguma ser realizado por uma Corte constitucional, e enfim atribui aos demais juízes a função de avaliar a convencionalidade de leis contrárias a tratados. Dois detalhes adicionais devem ser lembrados. Primeiro, a hierarquia diferenciada dos tratados está condicionada pela Constituição francesa atual à reciprocidade dos demais signatários. Segundo, para entrarem em vigor, os tratados internacionais devem ser previamente avaliados em relação a sua constitucionalidade. Enfim, caso o ConseIho constitucional verifique algum ponto de não adequação em relação ao parâmetro constitucional, a incorporação do tratado deve ser feita por meio de uma reforma constitucional.

Disso tudo resulta que tratados internacionais em vigor no direito francês são necessariamente constitucionais, o que afasta por completo a possibilidade de que o exercício pelas instâncias inferiores do controle de convencionalidade gere decisões contrárias ao texto constitucional e leva à necessidade de implantação de um sistema de controle de compatibilidade de leis em relação a tratados. ${ }^{45} \mathrm{O}$ problema é que a combinação de tais condições raramente sistemas jurídicos americanos, onde muitas vezes se atribui uma hierarquia normativa diferenciada a tratados internacionais de proteção de direitos humanos ${ }^{46}$ mas em regra se adota a sistemática repressiva de controle de constitucionalidade das leis. ${ }^{47}$ Nestas condições, não tem nenhum sentido importar a noção francesa de convencionalidade, que foi talhada para ser aplicada em um sistema de controle puramente preventivo. Nesse caso, como já foi aqui observado, uma vez que se admita a verificação posterior da constitucionalidade de uma norma, bastará aferir se as leis e os tratados que integram o ordenamento estão de acordo com os parâmetros da Constituição. Sem convencionalidade.

Paralelo a tudo isso surgiu uma proposta alternativa e radical de fundamentação: o controle de convencionalidade seria uma via para a efetivação da maior proteção dos direitos humanos e fundamentais (pro homine ou favor persona), justificativa que se sobrepõe a todas as demais e torna desnecessário o recurso a dispositivos específicos

\footnotetext{
45 Para a análise de tal procedimento de controle, cf DRAGO, Guillaume. Contentieux constitutionnel français. 3. ed. Paris: PUF., p. 573 e 574, onde se afirma que o procedimento de controle dos tratados se destina a "prévenir tout conflit normatif entre um engafement international et la Constitution".

46 Para uma relação dos países que atribuem status diferenciado aos tratados internacionais de direitos humanos, ver: DULITZKY, Ariel. La aplicación de los tratados de derechos humanos por los tribunales locales: un estudio comparado. In: ABREGÚ, Martin; COURTIS, Christian (Org.). La aplicación de los tratados sobre derechos humanos por los tribunales locales, Argentina: Ed. del Puerto, 1997. p. 49.

47 O Chile é uma exceção a essa regra, pois a constituição adota ao mesmo tempo as sistemáticas de controle preventiva e repressiva. Contudo, esse caso também não afasta a conclusão aqui defendida, pois a concomitância desses dois modos de controle afasta a necessidade de qualquer outra modalidade de aferição que não seja controle de constitucionalidade. Contra, afirmando que o sistema Chileno comporta também o controle de convencionalidade: ALCALÁ, Humberto Nogueira. Reforma constitucional de 2005 y control de constitucionalidade de tratados internacionales. Estudios Constitucionales, Talca, vol. 5, n. 1, 59-88, 2007. p. 62.
} 
de Convenções internacionais que autorizem a aplicação dessa técnica de controle. ${ }^{48}$ Nesse caso, o argumento que sustenta a existência do controle de convencionalidade não é só problemático, mas também obscuro. ${ }^{49}$ Não se sabe, afinal, o que na prática se altera no que diz respeito ao nível de satisfação de um direito humano ou fundamental com a criação de um novo instrumento de controle. A julgar pelo que se observa da prática do controle de constitucionalidade, que muitas vezes é também fundamentado na necessidade de se proteger minorias políticas e sociais, a resposta a essa questão seria simplesmente: muito pouco ou nada, pois a existência de instrumentos jurisdicionais de controle não garante que o resultado do julgamento será necessariamente a favor da proteção do direito humano ou fundamental. ${ }^{50}$ Soma-se a isso que, na lógica da ponderação adotada neste ponto pelos defensores da convencionalidade, ${ }^{51}$ a proteção de um direito humano ou fundamental deve necessariamente implicar a restrição de outro, do que se extrai a consequência de que a proteção realizada pelo julgamento que aplica a convencionalidade sempre resulta na não proteção do julgamento que não aplica essa técnica. ${ }^{52} \mathrm{E}$ isso quer dizer simplesmente que, não só a proteção, mas também o instrumento de controle em questão é seletivo e arbitrário por natureza: ele existe e é aplicado desde que auxilie a finalidade perseguida pelo julgador.

48 Com essa justificativa: CONCl, Luiz Guilherme Arcaro. O controle de convencionalidade como parte de um constitucionalismo transnacional fundado na pessoa humana. Revista de processo, São Paulo, vol. 39, n. 232, p. 363-390, jun. 2014.; BAZÁN, Victor. O controle de convencionalidade e a necessidade de intensificar um adequado diálogo jurisprudencial. Revista direito público, vol. 8, n. 41, p. 218-235, set./out. 2011.

49 Na avaliação crítica de Leonardo Martins e Thiago Oliveira Moreira, o argumento que busca sustentar o controle de convencionalidade na prevalência da regra mais benéfica ao ser humano (pro homine) é pseudo-jurídico e falacioso, pois "a escolha de um parâmetro normativo não pode ser submetida a tal ponderação de resultados, quase como se o operador do direito estivesse em um supermercado de normas" (MARTINS, Leonardo; MOREIRA, Thiago Oliveira. Controle de convencionalidade de atos do poder público - concorrência ou hierarquia em face do controle de constitucionalidade?. In: PAGLIARINI, Alexandre Coutinho; DIMOULIS, Dimitri (Coord.). Direito constitucional internacional dos direitos humanos. Belo Horizonte: Fórum, 2012. p. 301).

50 Algumas análises empíricas indicam que "as visões políticas da Corte nunca são, por muito tempo, dissociadas das visões políticas dominantes nas maiorias que legislam" (DAHL, Robert. Tomada de decisão na democracia - a Suprema Corte como instituição nacional de tomada de decisão política. In: MENDES, Gilmar Ferreira; GALVÃO, Jorge Octávio Lavocat; MUDROVITSCH, Rodrigo Bittencourt (Org.). Jurisdição constitucional em 2020. São Paulo: Saraiva, 2016. p. 470).

51 A ideia de ponderação teve grande prestígio no direito brasileiro, a ponto de ser considerada por alguns como o novo paradigma do direito. Recentemente alguns estudos têm apresentado uma visão crítica a seu respeito. Dentre eles, cite-se: LAURENTIIS, Lucas Catib de. A proporcionalidade no direito constitucional: origem, modelos e reconstrução dogmática. São Paulo: Malheiros, 2017; MARTINS, Leonardo. Proporcionalidade como critério de controle de constitucionalidade: problemas de sua recepção pelo direito e jurisdição constitucional brasileiros. Cadernos de Direito, Piracicaba, vol. 5, n. 3, p. 15-45, jul./dez. 2003.

52 Até mesmo defensores convictos do controle de convencionalidade reconhecem a fragilidade de tal fundamentação. Exemplo disso está na afirmação de André Carvalho Ramos, segundo a qual a interpretação pro homine "sobre desgaste profundo pelo reconhecimento da existência da interdependência e colisão aparente entre os direitos, o que faz ser impossível a adoção desse critério no ambiente do século XXI no qual há vários direitos (de titulares distinto) em colisão" (RAMOS, André Carvalho. Curso de direitos humanos. 4. ed., São Paulo: Saraiva, 2017, p. 108. 
O controle de convencionalidade funciona, assim, como elemento de desestabilização e dissolução do sistema jurídico como um todo. Sua aplicação, afinal, não está voltada a preservar a hierarquia entre a norma controlada e o parâmetro de controle, mas sim a nivelar e relativizar a função desses dois polos, do que resulta a eliminação da própria função do instrumento de controle. Desestabilizador e sem cumprir a função mais elementar dos instrumentos de controle, o conceito de convencionalidade sobrevive, enfim, com o recurso de seus defensores a abstrações e conceitos morais altamente indeterminados. ${ }^{53}$ Frente a essa forma de justificação, pode-se recordar uma constatação de Carl Schmitt: "Responder a questões de competência indicando o aspecto material significa considerar alguém como louco".54 E em um mundo em que os limites entre a sanidade e a loucura são cada vez mais imprecisos, é preferível renunciar ao conceito mais do que controverso de convencionalidade do que abdicar da objetividade do sistema jurídico.

\section{CONTROLE SEM CONTROLE}

Controlar é valorar negativamente. Todo julgamento é, por isso, em sentido amplo, um ato de controle. O juiz de uma partida de futebol controla a conduta dos jogadores; o fiscal de rendas controla o recolhimento de impostos; o tribunal de contas controla a execução orçamentária; a corregedoria, enfim, controla a conduta dos servidores. Mas quando se trata de controle normativo, a questão é diversa. Se está em questão a validade de leis ou atos normativos que afrontem parâmetros que lhe são superiores, há uma série de instrumentos, procedimentos e requisitos que direcionam e condicionam a realização do ato do controle. É exatamente por isso que neste caso se fala em sistema de controle de constitucionalidade, enquanto nos demais casos de, fala-se em controle, simplesmente. Essa distinção tem consequências práticas e dogmáticas importantes. ${ }^{55}$

53 Essa forma de justificação é aplicada quando juízes da Corte interamericana de direitos humanos recorrem a imagens hiperbólicas como "as leis da humanidade", "o clamor universal", ou enfim a "o despertar da consciência jurídica universal", termos esses utilizados no voto concordante do juiz Cançado Trindade no julgamento do caso Barrios altos v. Peru (sentença de 14 de março de 2001). Assim como ocorre no caso da expressão pro homine, o conteúdo altamente abstrato e completamente indefinido de tais termos deixa na mão do julgador a escolha do resultado do julgamento, substituindo a objetividade da lei e do tratado pela subjetividade e pelo voluntarismo do julgador.

54 SCHMITT, Carl. Teologia política, Belo Horizonte: Del Rey, 2006. p. 31.

55 A noção de sistema de controle de constitucionalidade designa um conjunto amplo de regras procedimentais distintas das utilizadas nos procedimentos jurisdicionais ordinários. Dentre tais diferenças, podem ser citadas: a causa de pedir aberta; a não exigência de demonstração de interesse processual de alguns legitimados das ações diretas de inconstitucionalidade; enfim, a possibilidade de a sentença de mérito ser afastada por decisão legislativa posterior. No mesmo sentido, confrontando a sistemática processual ordinária e o sistema de controle de constitucionalidade, ver: DIMOULIS, Dimitri; LUNARDI, Soraya. Curso de processo constitucional. São Paulo: Atlas, 2013, p. 266 e ss. 
E no controle convencionalidade, o controle exercido pelos órgãos estatais tem as mesmas características do sistema de controle de constitucionalidade? Sergio Garcia Ramírez, um dos criadores dessa noção, ${ }^{56}$ responde afirmativamente, sustentando que "a convencionalidade possui, no âmbito externo, um significado semelhante ao que se atribui à constitucionalidade no âmbito interno".57 Neste ponto, é preciso ter muito cuidado com as aproximações. A inconstitucionalidade não é uma incompatibilidade normativa qualquer e seus efeitos não são derivados de uma inferência lógica extraída da constatação da violação de um parâmetro constitucional. ${ }^{58}$ Ao contrário, a determinação do conteúdo e alcance da noção de inconstitucionalidade deriva da valoração simultânea de algumas ideias: a representatividade dos atores políticos que aprovaram a norma controlada; a rigidez e estabilidade dos parâmetros normativos que integram o texto constitucional; enfim, a função exercida pelos tribunais ao confrontar os textos legais com as normas constitucionais.

A combinação de todos esses elementos determina as características do sistema de controle de constitucionalidade e não há uma só solução para essa relação. É possível atribuir a competência de controle a todos os órgãos jurisdicionais, excluindo autoridades políticas dessa função; há a alternativa de se concentrar a atribuição de aplicação da sanção de inconstitucionalidade em um único órgão, que pode assumir funções jurisdicionais ou não; enfim, existe a possibilidade de se excluir completamente a função de controle das autoridades jurisdicionais, transferindo essa função para órgãos puramente políticos. ${ }^{59}$ Essas alternativas têm consequências diferentes para a consolidação das ideias de democracia e proteção dos direitos garantidos em nível constitucional. Nenhuma delas contém uma verdade absoluta e incontestável e, por isso mesmo, é necessário que o sistema indique com precisão a autoridade que detém competência para aplicar a sanção de inconstitucionalidade. Esse elemento determina a natureza da sanção aplicada aos juízos de invalidade normativa, o que por sua vez determina o procedimento a ser seguido para que essa consequência seja atingida.

\footnotetext{
56 De fato, o primeiro caso da jurisprudência da Corte interamericana em que se menciona o termo inconvencionalidade foi Myrna Mack Chang vs. Guatemala, de 25 de novembro de 2003, quando em seu voto o juiz Sergio Garcia Ramírez menciona o termo "controle de convencionalidade" para se referir à responsabilidade de todos os órgãos do Estado frente às obrigações derivadas da Convenção.

57 RAMÍREZ, Sergio Garcia. El control judicial interno de convencionalidad. In: MAC-GREGOR, Eduardo Ferrer (Coord.). El control difuso de convencionalidad: Diálogo entre la Corte Interamericana de Derechos Humanos y los jueces nacionales. México: Fundap, 2012, p. 214.

58 Nessa linha, afirmando que "o juízo de inconstitucionalidade não se reduz a algo de lógico-formal ou silogístico", ver: MIRANDA, Jorge. Manual de direito constitucional: inconstitucionalidade e garantia da constituição. 3. ed. Coimbra: Coimbra Editora, 2008, p. 94.

59 São, respectivamente, as características dos sistemas de controle americano, austríaco e francês. Para uma exposição das diferentes características de tais sistemáticas, ver: RAMOS, Elival da Silva. Controle de constitucionalidade no Brasil: perspectivas de evolução. São Paulo: Saraiva, 2010.
} 
Todos esses conceitos estão extremamente dispersos e incertos quando se fala em controle de convencionalidade das leis. O caso que inaugura a série de manifestações da Corte interamericana de direitos humanos a respeito dessa técnica serve aqui de exemplo. Ali se diz que, apesar do "império da lei", ao qual os juízes internos estão sujeitos, "quando um Estado ratifica um tratado internacional como a Convenção americana, seus juízes, como parte do aparato estatal, também estão submetidos a ela, o que os obriga a velar para que os efeitos das disposições da Convenção se se vejam diminuídos pela aplicação de leis contrárias", disso resultando, ainda segundo as palavras da $\mathrm{CIDH}$, que todos os órgãos do poder judiciário devem exercer "uma espécie de controle de convencionalidade entre as normas jurídicas internas aplicadas a casos concretos e a Convenção americana sobre direitos humanos".60 Causa perplexidade o raciocínio circular que é aqui apresentado: se juízes estão sujeitos à lei e também à convenção, o que leva à conclusão de que se deve afastar a aplicação daquelas normas e não destas? A resposta a essa questão não está na simples afirmação de que o Estado se comprometeu a cumprir os tratados internacionais, pois os agentes estatais se comprometem também a respeitar as leis de um país, sobretudo se essas leis têm status constitucional. Solucionar esse paradoxo exige, portanto, a indicação de uma norma que autorize a CIDH e também os demais juízes a declararem a invalidade de leis e atos normativos com fundamento em disposições normativas de tratados internacionais. Mas como foi exposto no item anterior tal disposição não existe. Sem isso, tudo o que se pode extrair dessa afirmação da CIDH é que os acordos internacionais, tratados inclusive, devem ser respeitados pelos Estados signatários, sem que se possa extrair dessa simples afirmação qual a consequência do descumprimento dessas obrigações.

Nesse ponto, o controle de convencionalidade se apresenta como incompleto e paradoxal. Sua incompletude se situa no fato de se tratar de um instrumento de controle normativo que não está fundado na ideia de invalidade da norma nacional controlada, mas sim, como a própria $\mathrm{CIDH}$ diz, na responsabilidade do Estado em relação às obrigações internacionais por ele assumidas. Mas não se deve confundir responsabilidade internacional com o controle de convencionalidade. É perfeitamente possível, também desejável, que Estados violadores de normas de proteção de direitos humanos sejam responsabilizados perante organismos internacionais, responsabilização essa que pode assumir inúmeras formas e espécies: sanções comerciais, como embargos econômicos; políticas, como a expulsão de organismos internacionais; enfim, em casos mais drásticos e com a aprovação do Conselho de segurança das Nações unidas, se admite até mesmo a aplicação de sanções militares. ${ }^{61}$ Para o caso do continente ame-

60 Sentença do caso Almonacid Arrellano e outros v. Chile, de 26 de setembro de 2006.

61 Há intenso debate a respeito da eficácia e das características de tal sistema sancionatório. A esse respeito, listando as hipóteses de sanção previstas na legislação internacional e defendendo a sua eficácia: DINH, Nguyen Quoc; DAILLIER, Patrick; PELLET, Alain. Direito internacional público. Lisboa: Calouste Gulbenkian, 2003, p. 84. 
ricano, a Carta da organização dos Estados americanos (OEA) é expressa ao admitir a aplicação de sanções, dentre as mais graves, a suspensão de Estados-membros, que deve decorrer de votação qualificada da assembleia geral desse órgão. Nenhuma dessas hipóteses de responsabilização representa uma espécie de controle normativo. Nem poderia, pois o fato de o Estado nacional ser responsabilizado internacionalmente indica que existe um ato que infringe a norma internacional, ato esse que deixa de existir quando se admite que o mesmo tribunal que deve responsabilizar o Estado também tem o poder de anular a lei, ou ato normativo, violador. ${ }^{62}$ Tudo isso se resume na constatação, que é endossada pela própria $\mathrm{CIDH}$, de que o direito interno é considerado como um simples fato perante os tribunais internacionais. ${ }^{63}$ Realmente, mas fatos não são válidos ou inválidos; normas, ao contrário, são. E como sem o juízo de invalidade não há controle normativo, fica evidente que, paradoxalmente, sob a ótica da própria Corte que criou o estranho conceito do controle de convencionalidade, esse não é um instrumento de controle.

Finalmente, todas os problemas conceituais do controle de convencionalidade são potencializados pela noção confusa e obscura do "duplo controle".64 É difícil compreender a razão de se denominar e qualificar o controle normativo de um determinado país com o adjetivo "duplo". Afinal, sob o ângulo dos instrumentos e dos níveis de controle, o sistema é obviamente composto por múltiplas vias de verificação da validade das leis e dos atos normativos: há instrumentos de controle principal e incidental, aplicados em momentos prévio ou posterior à produção normativa, que, enfim, podem ser julgados segundo os critérios político ou judicial. No direito brasileiro, isso tudo resulta em um complexo sistema com diversas ações de controle propostas na via direta, somado a uma infinidade de possibilidades de questionamento da validade de leis ou atos normativos na via incidental. Soma-se a isso que a verificação da validade de atos normativos não está restrita à análise de sua constitucionalidade; é possível também que um ato normativo infralegal esteja em desacordo com o parâmetro legal que lhe

62 Similar, afirmando que a própria noção de responsabilidade internacional pressupõe que o Estado possa infringir as normas que integram os tratados internacionais: CONTESSE, Jorge. The Final Word? Constitutional Dialogue and the Inter-American Court of Human Rights. I-CON, [s.I.], vol. 15, n. 2, p. 414-435, 2017, p. 421.

63 Com fundamento em pareceres consultivos da Corte interamericana e sustentando que "as instâncias internacionais apreendem as leis internas, inclusive as normas constitucionais, como meros fatos, analisando se houve ou não violação das obrigações internacionais assumidas pelo Estado", ver: RAMOS, André CarvaIho. Responsabilidade internacional do Estado por violações de direitos humanos. Revista CEJ, Brasília, n. 29, p. 53-63, abr./jun. 2005, p. 56. Esta visão também é adotada pelo Draft Articles on Responsibility of States for Internationally Wrongful Acts que em seu artigo 12 dispõe que: "There is a breach of an international obligation by a State when an act of that State is not in conformity with what is required of it by that obligation, regardless of its origin or character".

64 Utilizando essa terminologia, por muitos: CAMPOS, Bárbara Pincowsca Cardoso. Controle de convencionalidade: aproximação entre direito internacional e constitucionalismo?. Revista do instituto brasileiro de direitos humanos, [s.l.], vol. 13, n. 13, p. 47-58, 2013, p. 53; GOMES, Eduardo Bianchi. Controle de convencionalidade nos processos de integração - Democracia e Mercosul (a construção de uma tese). A\&C - Revista de Direito Administrativo e Constitucional, Belo Horizonte, ano 13, n. 52, p. 231-245, 2013, p. 235. 
dá sustentação, caso em que o vício que fulmina a sua validade será a ilegalidade. Enfim, uma determinação individual pode estar em desacordo com a regulamentação administrativa e assim por diante, indefinidamente. Isso mostra que os níveis de validação e as possibilidades de invalidação de atos normativos produzidos dentro de um mesmo sistema jurídico são múltiplos, e não "duplos".

Essa multiplicidade de níveis de controle contrasta, por outro lado, com a unicidade do critério de validação das leis ou atos normativos que integram um mesmo sistema jurídico. Aqui as exigências de coerência interna e a estabilidade afastam a possibilidade de coexistência de duas ou mais cadeias de fundamentação normativa. Direito, moral, religião, entre outros, configuram por isso sistemas autônomos de fundamentação e validação normativos, sem que se possa afirmar que o conflito de uma regra de um deles com um parâmetro do outro seja a causa da invalidade de uma destas normas. ${ }^{65}$ Da mesma forma, os parâmetros e critérios de validação das normas constitucionais e internacionais são paralelos, independentes e incomunicáveis, pois derivam de fontes normativas diversas. ${ }^{66}$

Quando se diz, portanto, que uma norma é simultaneamente constitucional e inconvencional, ou então ao contrário, inconstitucional e convencional, se afirma ao mesmo tempo uma obviedade e uma contradição. De fato, é obvio que um mesmo ato pode ser considerado válido sob o ponto de vista do direito de um país, mas também uma afronta das normas internacionais: isso só reafirma e comprova que os parâmetros de validação e responsabilização dessas duas ordens normativas são independentes.

Por outro lado, quando se propõe que um mesmo juiz possa, de forma simultânea, afirmar que uma lei ou ato normativo é constitucional e inconvencional, chegando à conclusão de que a norma é inválida, o que na verdade ocorre é a substituição de um fundamento de validação por outro. No caso, do parâmetro constitucional pelo convencional. ${ }^{67} \mathrm{O}$ que definitivamente não pode ocorrer é a concomitância dos critérios de invalidação. Caso contrário existiria a possibilidade de uma norma válida inválida, o que equivale a dizer que a dizer que algo é e não é, ao mesmo tempo.

Como já foi aqui afirmado, essa modificação de parâmetro e sistemas de controle deve ser fundamentada em uma norma de reconhecimento comum, que ao mesmo tempo afaste o parâmetro constitucional e transfira a competência decisória para

65 Cf. a esse respeito: KELSEN, Hans. O problema da justiça. São Paulo: Martins Fontes, 1998.

66 Nessa linha: POTACS, Michael. Das Verhältnis zwischen der EU und ihren Mitgliedstaaten im Lichte traditioneller Modelle. ZÖR, [s.I.], n. 65, 117-139, 2010, p. 120.

67 Nem mesmo Alfred Verdross, um conhecido defensor do monismo, defende essa possibilidade, como se observa na seguinte passagem: "A distinção entre direito internacional e direito estatal se apresenta claramente quando consideramos as perspectivas de um juiz nacional e de um tribunal internacional. Enquanto a autoridade judicial nacional, na qualidade de órgão de um determinado Estado, deve aplicar até mesmo as leis que contrariam as normas internacionais, os tribunais internacionais, como órgãos do direito internacional, devem necessariamente aplicar as leis internacionais" (VERDROSS, Alfred. Völkerrecht. 3. ed. Wien: Springer, 1955 , p. 64, tradução livre). 
a instância internacional, o que não existe nem mesmo no continente Europeu, onde uma grande parcela da competência decisória dos Estados membros do bloco foi transferida para a União europeia. ${ }^{68}$ De toda forma, definitivamente não há nisso tudo um "duplo controle". Há a simples e pura substituição do controle de constitucionalidade que, diga-se, está fundamentado em normas de reconhecimento expressas no texto constitucional, por uma modalidade de controle da validade de atos normativos, a convencionalidade, que não é nem mesmo citada em nenhuma convenção ou tratado internacional da atualidade. Isso não é só uma forma de se trocar o certo pelo duvidoso, mas também uma via para a substituição do direito pela a opinião pessoal do julgador. E essa é a via de entrada em cena não só do ativismo convencional, mas também do moralismo jurídico e do arbítrio judicial, o que definitivamente não está de acordo com a noção de autonomia individual, que é um dos principais fundamentos dos direitos humanos.

\section{CONTROLE SEM PROCEDIMENTO}

Enquanto exercício do poder estatal, o controle de leis ou atos normativos deve seguir formalidades e ritos que tornem previsíveis e calculáveis não só o andamento, mas também as consequências das decisões que o aplicam. Essas precauções nascem da consciência empiricamente comprovada de que os sistemas de controle, quando mal regulamentado, podem ser a porta de entrada para as mais diversas formas de arbítrio, que vão desde a manipulação do conteúdo do julgamento até a construção de princípios e procedimentos não previstos em lei. Os procedimentos a que estão submetidos os atos de controle afiançam o uso legítimo desses instrumentos. Por meio deles, o próprio controle se torna controlável e, por isso, democraticamente justificado. ${ }^{69}$ Essa correlação é quebrada quando julgadores passam a criar procedimentos de controle não previstos anteriormente em lei, o que faz surgir a dúvida a respeito de quem aciona, como se realiza, quem julga e, enfim, quem será afetado por esse ato de poder. É exatamente isso o que ocorre com a aplicação do controle de convencionalidade.

As dificuldades começam com a denominação. O controle de convencionalidade é ora denominado de concentrado quando é exercido pela $\mathrm{CIDH}$, ora difuso, quando é exercido por todos os juízes que integram as ordens estatais submetidas à

\footnotetext{
68 Contudo, mesmo no âmbito da União Europeia não há instrumento equivalente ao controle de constitucionalidade, pois lá se trabalha com o conceito de margem de apreciação estatal. Nesse sentido, comparando os sistemas de proteção de direitos humanos europeu e latino-americano, ver: CONTRERAS, Pablo. National discretion and international deference in the restriction of human rights: a comparation between the jurisprudence of the European and inter-american Court of human rights. Northwestern journal of international human rights, [s.I.], vol. 11, n. 28, p. 28-82, 2012, p. 59- 60.

69 Cf. LAURENTIIS, Lucas De; GALKOWICZ, Henrique. Medidas cautelares interpretativas e de efeito aditivos no controle de constitucionalidade: uma análise crítica de sua aplicação. Revista Direito GV, São Paulo, n. 21, p. 65-88, 2015.
} 
jurisdição desta Corte. ${ }^{70}$ Mas é evidente que as noções de controle difuso e concentrado são opostas e excludentes, já que a difusão da competência de controle indica que todo e qualquer juiz pode controlar a validade de atos normativos e a concentração, ao contrário, indica que só um tribunal pode exercer essa competência sancionatória. Por impossibilidade lógica, não há, portanto, um sistema difuso concentrado, assim como não há um sistema misto de controle de convencionalidade ou, então, constitucionalidade. ${ }^{71}$ Há aqui, portanto, duas hipóteses excludentes: ou a CIDH é o único órgão competente para exercer o controle de convencionalidade, caso em que o sistema será concentrado, ou então todos os magistrados dos países signatários da Convenção americana de direitos humanos são competentes para exercer essa atribuição. No primeiro caso o sistema de controle interamericano se aproximaria de um modelo europeu, com jurisdição concentrada e legitimação restrita para acesso ao tribunal que exerce o controle; já na segunda hipótese haveria grande semelhança com o modelo de controle de constitucionalidade norte americano, que desde é caracterizado pela difusão da competência de controle e pela limitação subjetiva dos efeitos da declaração de inconstitucionalidade.

Cada uma dessas formas de organização da competência de controle traz consigo uma sistemática processual específica, por meio da qual são determinadas as circunstâncias que cercam a declaração de invalidade dos atos normativos. No caso europeu, em regra se atribui somente a atores políticos ou órgãos com grande representatividade social o poder de arguir a invalidade de leis e atos normativos perante os órgãos de controle; justamente o contrário do que ocorre no sistema norte-americano, onde todo e qualquer cidadão que se julgue afetado por uma lei inconstitucional pode requerer a um juiz ou tribunal a declaração da invalidade dessa norma. Isso determina também o manejo de instrumentos recursais para acesso ao órgão de controle, possibilidade que é clara e terminantemente vedada no sistema de controle europeu e, por outro lado, é amplamente admitida na sistemática de controle norte-americana. Qual foi o modelo adotado pela Corte interamericana quando se criou a noção de inconvencionalidade?

Não há uma resposta convincente da Corte interamericana a essa questão. No que diz respeito à competência de controle há uma primeira indefinição. Se em um

70 Expressamente e nesse sentido: MAC-GREGOR, Eduardo Ferrer. Interpretación conforme y control difuso de convencionalidad: el nuevo paradigma para el juez mexicano. Estudios Constitucionales, Talca, vol. 9, n. 2, p. 531-622, 2011, p. 559, onde se afirma que "El control de convencionalidad tiene dos manifestaciones: una de caracter "concentrada" por parte de la Corte Interamericana, en sede internacional; y otra de caracter "difusa" por los jueces nacionales, en sede interna". Na mesma linha CAMILO, Guilherme Vitor de Gonzaga. A aplicação dos tratados e a doutrina do controle de convencionalidade: bases jurídicas e efetivação. Revista de direito brasileira, São Paulo, vol. 17, n. 7, p. 18-39, maio/ago. 2017, p. 28.

71 De longa data, nesse sentido: RAMOS, Elival da Silva. A inconstitucionalidade das leis: vício e sanção. São Paulo: Saraiva, 1994. Mais recente e com as mesmas conclusões: DIMOULIS, Dimitri; LUNARDI, Soraya. Curso de processo constitucional. São Paulo: Atlas, 2013, p. 74. 
primeiro momento esse poder foi atribuído a todos os juízes nacionais, ${ }^{72}$ logo depois houve a expansão dessa competência para todos os órgãos de Estado que exerçam função jurisdicional, mesmo que não integrantes do poder judiciário, ${ }^{73}$ para finalmente se ampliar essa atribuição a ponto de se autorizar que todo e qualquer órgão ligados à administração da justiça, ou autoridade administrativa, ${ }^{74}$ possam exercer essa competência. Ubiquitário e universal, o controle de convencionalidade está em toda a parte.

Mais do que um problema acidental, esse movimento de "avanços e retrocessos"75 na determinação dos órgãos que detêm a competência para o exercício do controle de convencionalidade indica uma inconsistência normativa e sistemática da convencionalidade. Sob o enfoque normativo, não há como se admitir que uma instância julgadora crie para si mesma a competência de avaliar, em abstrato e com efeitos gerais, a constitucionalidade ou a convencionalidade de um ato normativo. O único caso que se tem notícia de um tribunal que tenha realizado semelhante usurpação de poder ocorreu em Israel, onde por via interpretativa se admitiu a criação de um instrumento de controle principal. ${ }^{76}$ Alguns anos depois, a CIDH seguiu o mesmo caminho, sem considerar as consequências desastrosas da opção israelense para a construção da democracia e para a proteção dos direitos humanos. ${ }^{77}$ Sob o ponto de vista sistemático, a transformação de todos os juízes do continente americano em potenciais defensores da convencionalidade é uma opção que agride o próprio texto da Convenção americana de direitos humanos, pois, ao difundir essa competência sancionatória, a CIDH se converte em instância revisora de todo e qualquer julgamento interno que declare a invalidade de um ato normativo em função de sua inconvencionalidade. Isso é

72 Caso Almonacid Arrellano e outros v. Chile, sentença de 26 de setembro de 2006, parágrafo 124. Nessa ocasião a Corte IDH já fala em "obrigação", mas a utilização do termo técnico jurídico "controle de ofício" foi utilizado, no mesmo ano, no julgamento do caso Trabalhadores demitidos do Congresso v. Peru, sentença de 24 de novembro de 2006.

73 Esta conclusão é extraída por derivação da decisão do caso Vélez Loor v. Panamá, sentença de 23 de novembro de 2010. parágrafos 141 e 142

74 Respectivamente: Caso Cabrera García e Montiel Flores vs. México, sentença de 26 de novembro de 2010, parágrafo 225.Corte IDH. Caso Gelman vs. Uruguai, sentença de 24 de fevereiro de 2011, parágrafo 193.

75 Cf., a esse respeito: MOREIRA. O Exercício do Controle de Convencionalidade pela Corte Interamericana de Direitos Humanos: Uma Década de Decisões Assimétricas. In. MENEZES, Wagner (Org.). Direito Internacional em Expansão. Anais do XV CBDI. Belo Horizonte: Arraes Editores, 2017, p. 251- 271, p. 269.

76 A esse respeito, buscando justificar a concepção israelense: BARAK, Ahron. The judge in a Democracy, Princeton and Oxford: Princeton University Press, 2006, p. 296. Qualificando essa opção como um caso de despotismo esclarecido: POSNER, Richard. Enlightened Despot, The New Republic, [s.I.], [s.n.], 23 de abril, 2007, p. 53.

77 Dentre as medidas autorizadas pela Suprema Corte israelense com base na retórica da defesa da democracia e dos direitos humanos estão: a construção de um muro de segregação da Cisjordânia; a autorização de prisões administrativas e do emprego da tortura; a realização da demolição de casas e propriedades sem prévio processo judicial; enfim, o confisco sumário de terras e propriedades. Uma listagem completa dessas medidas e dos precedentes da Suprema Corte israelense que os admitiram pode ser encontrada em: SULTANY, Nimer. The legacy of justice Aharon Barak: a critical review. Harvard International Law Journal, Cambridge, vol. 48, p. 83-92, 2007, p. 84. 
justamente o oposto do que exige a Convenção, que condiciona o acesso ao sistema interamericano à comprovação do prévio esgotamento dos recursos internos. ${ }^{78} \mathrm{Afinal}$, se todo juiz pode julgar uma lei inconvencional, é mais do que evidente que não se exige mais que todas as instâncias julgadoras internas sejam acionadas, e muito menos que avaliem a validade de uma lei, para que a competência de revisão da Corte interamericana seja autorizada. ${ }^{79}$ Tudo somado, isso quer dizer que, ao criar a noção de controle de convencionalidade, a CIDH não só se apropriou de um poder que não lhe foi atribuído pela Convenção, mas também desconsiderou o papel que lhe foi atribuído por esse tratado. Um caso de proteção seletiva do texto convencional e dos direitos humanos.

O problema se agrava quando se considera que a competência sancionatória pode ser concentrada no interior de um sistema jurídico. Isso ocorre, por exemplo, com as constituições da Costa Rica, Chile e Uruguai, países que adotam uma variação do sistema europeu de controle de constitucionalidade e, por isso, afastam a competência de juízes singulares e tribunais locais para declarar a inconstitucionalidade de leis e atos normativos. Nessas situações, a difusão da competência do controle de convencionalidade cria duas situações paradoxais e altamente conflitivas. A primeira na hipótese de conflito ocorre quando um juiz de primeira instância passa a ser autorizado a afastar a aplicação da lei que julgue inconvencional, mesmo que a Corte constitucional de um desses países tenha decidido que essa mesma lei é válida tendo em vista os parâmetros constitucionais. ${ }^{80}$ Aqui o controle de constitucionalidade serve como uma via de escape dos efeitos vinculantes das decisões proferidas pelos tribunais constitucionais, gerando com isso insegurança e desestabilizando o sistema de controle como um todo. Não sem razão, os próprios defensores da convencionalidade tendem, em tais situações, a restringir a possibilidade de se avaliar a convencionalidade de leis ou atos normativos, exigindo que em sistemas de controle concentrado, só a autoridade competente para a análise da constitucionalidade das leis também seja autorizada julgar a convencionalidade dessas normas. ${ }^{81}$ Mas isso implica afastar a compreensão da Corte

\footnotetext{
78 Nos termos da Convenção Americana, para que uma petição seja apresentada à Comissão americana de direitos humanos, o peticionário deve comprovar que "hajam sido interpostos e esgotados os recursos da jurisdição interna, de acordo com os princípios de Direito Internacional geralmente reconhecidos" (art. 46, 'a').

79 Similar, sustentando que, ao criar o controle de convencionalidade, a Corte "afasta o princípio da subsidiariedade": DULITZKY, Ariel. An Inter-American Constitutional Court? The Invention of the Conventionality Control by the Inter-American Court of Human Rights. Texas International Law Journal, Texas, vol. 50, n. 1, p. 47-93, 2015, p. 55.

80 Abordando esse problema: BILDER, Christina. The prohibition of amnesties by the inter-American Court of Human Rights, German law journal, [s.l.], vol. 12, n. 5, p. 1203-1230, 2011, p. 1216-1217; CONTESSE, Jorge. The Final Word? Constitutional Dialogue and the Inter-American Court of Human Rights, I-CON, [s.l.], vol. 15, n. 2, p. 414-435, 2017, p. 420.

81 Nessa linha, afirma Néstor Sagüés que o juiz incompetente para a análise da constitucionalidade "deberá remitir los autos al tribunal habilitado para ejercer el control de constitucionalidad, mediante el conducto procesal adequado" (SAGÜÉS, Nestor Pedro. Obrigaciones internacionales y control de convencionalidade. Estudios Constitucionales, Talca, vol. 8, n. 1, p. 117-136, 2010, p. 122).
} 
interamericana, segundo a qual todo e qualquer juiz deve necessariamente e de oficio afastar a aplicação de normas que contrariem parâmetros convencionais.

No Brasil as coisas se passam de forma diversa. Aqui o sistema de controle é marcado pela difusão da competência sancionatória, o que autoriza todo e qualquer juiz a reconhecer e avaliar a inconstitucionalidade de leis ou atos normativos. Nessa sistemática, como deve ocorrer a declaração da inconvencionalidade? Embora esse sistema de controle seja aparentemente mais suscetível à observância do que dispõe a jurisprudência interamericana, há de se considerar uma complexidade adicional: atualmente, o direito brasileiro reconhece ao menos dois níveis hierárquicos para os tratados internacionais de proteção de direitos humanos. Há o status supralegal, no qual, por construção jurisprudencial, ${ }^{82}$ foram inseridos os tratados de direitos humanos que passaram pelo rito ordinário de incorporação. $\mathrm{E}$, por outro lado, existem aqueles tratados incorporados pelo rito especial criado pela reforma constitucional de 2004 e que se assemelha ao procedimento de aprovação das emendas constitucionais. ${ }^{83}$ Nessa última hipótese não se pode falar de controle de convencionalidade, pois os tratados incorporados por esse procedimento diferenciado são incluídos no conceito de bloco de constitucionalidade. ${ }^{84} \mathrm{E}$ se o bloco é de constitucionalidade, o controle, por consequência óbvia e direta, também será de constitucionalidade, não de convencionalidade. ${ }^{85}$ Enfim, somente nessa hipótese, a consequência procedimental que se deriva é que todo o instrumental de controle de constitucionalidade brasileiro, incluindo os instrumentos de controle de omissões estatais, poderão ser manejados em casos de afronta a parâmetros normativos de tratados de direitos humanos que tenham status equivalente às emendas constitucionais. Mas isso decorre da norma que atribui essa posição diferenciada a essa categoria de tratado, não do controle de convencionalidade. ${ }^{86}$

82 Esse entendimento foi adotado pelo Supremo Tribunal Federal no julgamento do Recurso extraordinário 466.343-SP, rel. Min. Cezar Peluzo, julgamento em 3 de dezembro de 2008.

83 Há diferenças marcantes dos procedimentos de emenda constitucional (art. 60, CF/1988) e de incorporação de tratados de direitos humanos com equivalência de emenda constitucional (art. $5^{\circ}, \S 3^{\circ}, \mathrm{CF} / 1988$ ), sobretudo no que diz respeito aos legitimados para dar início ao procedimento e ao ato de promulgação. Detalhando e analisando essas peculiaridades procedimentais: LAURENTIIS, Lucas Catib de. Muito barulho pra nada: problemas do procedimento de recepção dos tratados de direitos humanos com hierarquia constitucional. In: LISBOA, Marcos José Alves; GASPAR, Renata Alvares (Org.). Direito globalizado, ética e cidadania. Belo Horizonte: Arraes editores, 2017. p. 54 e ss.

84 Acerca do conceito de bloco de constitucionalidade, ver: MONTEIRO, Marco Antonio Corrêa. Tratados internacionais de direitos humanos e direito interno. São Paulo: Saraiva, 2011, p. 157.

85 Com as mesmas conclusões: MARTINS, Leonardo; MOREIRA, Thiago Oliveira. Controle de convencionalidade de atos do poder público - concorrência ou hierarquia em face do controle de constitucionalidade?. In: PAGLIARINI, Alexandre Coutinho; DIMOULIS, Dimitri (Coord.). Direito constitucional internacional dos direitos humanos, Belo Horizonte: Fórum, 2012, p. 307.

86 Em sentido contrário, Valério de Oliveira Mazzuoli sustenta que este seria um caso de controle de convencionalidade, não de constitucionalidade, pois a norma constitucional (art. $5^{\circ}, \S 3^{\circ}$ ) torna o tratado internacional equivalente e não igual às normas constitucionais, chegando à conclusão de que, neste caso, "a lei constitucional é, não obstante, inconvencional". (Cf. MAZZUOLI, Valério de Oliveira. O controle jurisdicional da 
Com isso, quando estiver em questão a afronta de uma norma inserida em tratado de direitos humanos com força equivalente às emendas constitucionais, a cláusula de reserva de plenário deverá ser aplicada, exigindo-se o voto favorável da maioria dos integrantes do órgão especial ou do plenário do tribunal para que seja declarada a inconstitucionalidade da norma controlada. As razões anteriores levam a essa conclusão: trata-se, também aqui, de avaliar a constitucionalidade da norma que afronta o tratado, do que se infere que o procedimento da reserva de plenário deve ser aplicado a essa hipótese. Enfim, admitido que nessa hipótese o vício normativo a ser sanado é a inconstitucionalidade, será possível manejar recursos extraordinários em face de decisões jurisdicionais de única ou última instância que contrariem dispositivos de tratados internacionais com força equivalente às normas constitucionais. Caso esse julgamento enseje a declaração de invalidade da norma controla, será necessário, enfim, acionar o procedimento de envio de comunicação ao Senado federal, para que eventualmente se suspenda, com efeitos gerais, a eficácia da norma. O fundamento para a interposição desse instrumento recursal é o mesmo dispositivo que autoriza a propositura do recurso extraordinário em casos de afronta às normas constitucionais. ${ }^{87}$

As questões se complicam, e muito, quando se tem em conta o controle de leis ou atos normativos que afrontem dispositivos de tratados incorporados pelo procedimento comum. Neste caso, como já se disse aqui, a jurisprudência do Supremo Tribunal Federal criou uma nova hierarquia normativa, que não está prevista no texto constitucional: a supralegalidade. Seriam aplicáveis, também nesse caso, os procedimentos e os instrumentos de defesa da Constituição? A resposta é negativa. Primeiro porque as ações diretas de controle são destinadas, como o próprio nome delas indica, a avaliar a constitucionalidade ou a inconstitucionalidade de leis ou atos normativos. Como esses conceitos não se confundem com a convencionalidade, tais instrumentos de controle não podem ser utilizados para controlar a conformidade de leis ou atos normativos em relação a tais parâmetros de aferição. Segundo porque, ao se admitir que um tratado de direitos humanos, que tenha sido alçado ao nível supralegal, sirva de parâmetro abstrato de controle, será possível ocorrer a situação insólita de duas ações diretas com sentidos divergentes serem propostas em um mesmo caso: uma delas defendendo a

convencionalidade das leis. 2. ed. São Paulo: Revista dos Tribunais, 2011, p. 146, grifos do original). O argumento é duplamente contraditório. Afinal, se a lei é contrária ao tratado, mas está de acordo com a constituição que atribuiu força constitucional ao tratado, isso quer dizer que o tratado está em desacordo com a constituição e, por isso, é inválido, por ser inconstitucional. E isso quer dizer que a sistemática de controle decorre, tem todos esses casos, da própria Constituição. Fora isso, ao utilizar a expressão equivalente, o texto constitucional realmente não transforma o tratado em constituição, mas empresta a eficácia das normas constitucionais aos tratados de direitos humanos, inclusive no que tange aos instrumentos de sua defesa. E se essas normas - as que estão nos tratados "equivalentes" às emendas - têm força de constituição, isso quer dizer que não é necessário criar um novo sistema de controle para defender esses tratados: basta o controle de constitucionalidade.

87 Trata-se do art. 102, III, a, da CF/1988, segundo o qual compete ao Supremo Tribunal Federal julgar "mediante recurso extraordinário, as causas decididas em única ou última instância, quando a decisão recorrida: a) contrariar dispositivo desta Constituição". 
constitucionalidade da lei, outra sua inconvencionalidade. Mas isso equivale a alçar os tratados em questão ao nível constitucional, o que contraria a própria jurisprudência que criou esse nível normativo inovador. Enfim, terceiro o eventual conflito entre normas localizadas em nível infraconstitucional será solucionado ou por meio da aplicação do critério da especialidade, ou da avaliação da constitucionalidade. Caso contrário, se incluiria dentro do sistema uma cadeia de invalidação independente, o que não é admissível. Assim, para que o controle de convencionalidade tenha um sentido independente do controle de constitucionalidade, é preciso admitir que, ao se concluir que uma lei é inconvencional, se afirma somente que essa lei interfere em uma matéria reservada aos tratados internacionais de direitos humanos. Nessa modalidade de aferição não está em jogo, portanto, a validade da lei ou ato normativo confrontado com o parâmetro da convenção; ${ }^{88}$ o que se verifica é única e exclusivamente se, e em que medida, a matéria debatida deve ser especificamente abordada pelo tratado ou pela lei. ${ }^{89} \mathrm{E}$ como esse juízo não envolve a invalidação de um ato normativo, não tem sentido manejar os instrumentos de controle direto (ADI e ADC) para analisar essa questão.

Pelas mesmas razões, em casos envolvendo o confronto entre tratado com nível supralegal e leis também não será necessário acionar o procedimento da reserva de plenário para afastar a aplicação da lei ou do próprio tratado. Uma dificuldade que poderia surgir aqui diz respeito à observância do que dispõe a Súmula vinculante de $\mathrm{n}$. 10, do Supremo Tribunal Federal, segundo a qual viola a cláusula de reserva de plenário a decisão judicial que, embora não declare a inconstitucionalidade do ato normativo controlado, afasta a sua incidência. Quando a esse ponto, é preciso esclarecer que o simples afastamento de uma norma em um caso específico não atrai necessariamente a incidência da reserva de plenário. Ao contrário, é preciso que esse afastamento esteja, implícita ou explicitamente, amparado em um juízo de invalidade, para que seja necessário acionar tal procedimento. Caso contrário, toda interpretação normativa que conclua pela aplicação de uma norma e afastamento de outra - o que ocorre com o critério da especialidade, por exemplo - exigiria a utilização da reserva de plenário. ${ }^{90} \mathrm{E}$

88 De maneira inversa, mas com os mesmos pressupostos, ao declarar a inconstitucionalidade de um tratado, o Supremo Tribunal Federal não invalida o conteúdo do próprio tratado, que é um acordo internacional e que, portanto, não está sujeito à jurisdição desta Corte. O que se declara inconstitucional em situações de conflito dos tratados internacionais em relação a parâmetros constitucionais é o ato de incorporação de tal acordo internacional no sistema jurídico brasileiro. Nesse sentido: CLÈVE, Clèmerson Merlin. A fiscalização abstrata de constitucionalidade no direito brasileiro. São Paulo: Revista dos Tribunais, 1995, p. 146.

89 De forma similar, sustentando que em casos de conflito de tratados e os demais atos normativos deve ser solucionado com base no critério da "conformação constitucional", ver: MARTINS, Leonardo; MOREIRA, Thiago Oliveira. Controle de convencionalidade de atos do poder público - concorrência ou hierarquia em face do controle de constitucionalidade?. In: PAGLIARINI, Alexandre Coutinho; DIMOULIS, Dimitri (Coord.). Direito constitucional internacional dos direitos humanos, Belo Horizonte: Fórum, 2012, p. 313.

90 Há jurisprudência do Supremo Tribunal Federal reiterada nesse sentido: "é permitido aos magistrados, no exercício de atividade hermenêutica, revelar o sentido das normas legais, limitando a sua aplicação a determinadas hipóteses, sem que estejam declarando a sua inconstitucionalidade. Se o Juízo reclamado não declarou a inconstitucionalidade de norma nem afastou sua aplicabilidade com apoio em fundamentos extraídos da 
justamente o que ocorre no caso do confronto de tratados e leis. Não se faz necessária, portanto, a aplicação da reserva de plenário em julgamentos colegiados que afastem a aplicação de leis ou atos normativos contrários a tratados de direitos humanos, pois esse caso não envolve, repita-se, um juízo de invalidação de tais normas.

Pelas mesmas razões, será incabível a propositura de recurso extraordinário que trate do conflito de tal categoria de tratados com outras leis. Isso por duas razões. Primeiro, essa hipótese não envolve, como já se disse aqui, um juízo de invalidade, quando menos de inconstitucionalidade da lei e o recurso extraordinário é um instrumento de revisão de juízos de invalidação fundamentados em normas constitucionais. Só por isso não tem sentido ou razão a propositura do recurso extraordinário. Segundo, no direito brasileiro, o interprete final do sentido da legislação infraconstitucional é o Superior Tribunal de Justiça, a quem também compete determinar as normas que incidem em um determinado conflito. ${ }^{91}$ Caberá a ele, portanto, Superior Tribunal de Justiça, decidir em última instância a respeito da prevalência da lei ou do tratado de direitos humanos, sem que o Supremo Tribunal Federal possa se imiscuir nesta temática. Para uma uniformização de entendimentos e concentração de competência para dirimir questões sobre direitos humanos no STF, uma alteração da Constituição parece ser inevitável ${ }^{92}$, e a exemplo do que ocorre em sistemas constitucionais estrangeiros, a corte constitucional seria competente para conhecer e julgar não só questões constitucionais como também às envolvendo espécies normativas dotadas de "valor" ou posição hierárquica privilegiada $^{93}$.

CF/1988, não é pertinente a alegação de violação à Súmula Vinculante 10" (Rcl 12.122 AgR, voto do rel. min. Gilmar Mendes, DJE 211 de 24 de outubro de 2013).

91 A respeito da distinção das hipóteses de cabimento do recurso extraordinário e especial, ver: MANCUSO, Rodolfo de Camargo. Recurso extraordinário e recurso especial. 10. ed. São Paulo: Revista dos Tribunais, 2007, p. 245 a 250.

92 MARTINS, Leonardo; MOREIRA, Thiago Oliveira. Constitucionalidade e Convencionalidade de Atos do Poder Público: concorrência ou hierarquia? Um contributo em face da situação jurídico-constitucional brasileira. Anuario de Derecho Constitucional Latino Americano, [s.I.], vol. 17, p. 463-483, 2011, p. 478. Para viabilizar o exercício do controle de convencionalidade dos tratados incorporados pelo rito do $\$ 3^{\circ}$ do art. $5^{\circ}$ da $\mathrm{CF}$ os autores sugerem a necessidade emendar o art. 102 para que conste expressamente caber ao STF a guarda não só da Constituição como também dos Tratados Internacionais de Direitos Humanos e reconheça a possibilidade de ação direta de inconvencionalidade e convencionalidade. Contudo, essa alteração se mostra desnecessária tendo em vista que os tratados que forem incorporados com o rito especial já integraram o bloco de constitucionalidade. Uma alteração nesse sentido seria útil apenas se for para transferir a competência de aferir violações às normas supralegais ao Supremo. Nesse mesmo sentido, uma alteração pertinente proposta pelos autores (p. 482) seria reconhecer a supralegalidade dos tratados de direitos humanos no art. 59 da CF, pois assim o controle de convencionalidade seria de fato um instrumento para aferir a compatibilidade dos atos normativos brasileiros com a normas dotadas de supralegalidade.

93 Para uma uniformização de entendimentos e concentração de competência para dirimir questões sobre direitos humanos no Supremo Tribunal Federal, uma alteração da Constituição parece ser, por isso, inevitável. Neste caso, a exemplo do que ocorre em sistemas constitucionais estrangeiros, a corte constitucional seria competente para conhecer e julgar não só questões constitucionais como também às envolvendo espécies normativas dotadas de "valor" ou posição hierárquica privilegiada. Em Portugal, por exemplo, o Tribunal Constitucional é competente para conhecer não só de questões constitucionais como também as ligadas a legalidade (controle de legalidade), desde que envolvam ilegalidade de atos normativos desconformes às leis com 
Resta, enfim, saber se e em que condições, órgãos externos ao poder judiciário podem realizar o controle de convencionalidade. Em relação ao poder legislativo, que no sistema brasileiro atua, em regra, ${ }^{94}$ em hipóteses de controle preventivo de constitucionalidade, o controle de convencionalidade poderia ser exercido, ao que parece, em uma única hipótese muito restrita: quando os tratados de direitos humanos incorporados em nível constitucional se caracterizarem como cláusulas pétreas. Aqui uma explicação é necessária: assim como nem todos os direitos fundamentais são automática e necessariamente cláusulas pétreas, ${ }^{95}$ não são todos os direitos inseridos em tratados de direitos humanos com nível constitucional que se qualificam como tal. ${ }^{96} \mathrm{Em}$ relação a esses direitos inseridos em tratados internacionais de proteção de direitos humanos e classificados como cláusulas pétreas, o controle prévio e parlamentar poderá ocorrer, inclusive com o acionamento do judiciário pela via de ação mandamental. ${ }^{97}$ Nos demais casos, considerando que o Parlamento tem a prerrogativa de alterar as leis e os parâmetros constitucionais, desde que não sejam feridas as cláusulas pétreas, não se pode cogitar de controle de constitucionalidade ou convencionalidade. Novamente aqui não é admissível o controle que tenha por fundamento um parâmetro inserido em um tradado de direitos humanos sem hierarquia constitucional, pois em relação a esses tratados o Legislativo detém tanto a competência de incorporação quanto de revogação do tratado.

Finalmente, há a questão da possibilidade do exercício do controle de convencionalidade por órgãos integrantes do Poder executivo. Na perspectiva expansionista da Corte interamericana de direitos humanos, a resposta a essa questão é direta: uma vez que todos os órgãos de Estado estão igualmente vinculados às obrigações

valor reforçado (no ordenamento português, são leis especiais quanto à forma, característica e função). Nesse sentido, conferir: art.112/3, CRP (sobre as leis de valor reforçado); art.280/2 e 281/1, CRP (competência do TC para o controle de legalidade); e CANOTILHO, J.J. Gomes. Direito Constitucional e Teoria da Constituição. 3. ed. Coimbra: Almedina, 1998. p. 862.

94 Há duas exceções a essa regra, uma delas relacionada ao procedimento de conversão em lei das medidas provisórias (art. 62, § 9०, CF/1988), outra relacionada ao controle parlamentar dos atos do executivo que extrapolam os limites da delegação legislativa (art. 49, V, CF/1988).

95 Nessa linha, sustentando que a localização topográfica de um direito no texto constitucional não o define, de forma automática, como cláusula pétrea: VIEIRA, Oscar Vilhena. A constituição e sua reserva de justiça. São Paulo: Malheiros, 1999, p. 145.

96 A obrigação descrita no artigo 31 da Convenção de Nova lorque, incorporado ao direito brasileiro em nível equivalente às emendas constitucionais pelo Decreto 6.949/09, trata da obrigação estatal de elaborar pesquisas estatísticas voltadas à implementação de políticas públicas na área de proteção dos direitos com pessoas com deficiência. Por mais que tais atos estatais sejam realmente importantes para o planejamento de tais ações estatais, não é possível caracterizar essa obrigação específica como uma parte do núcleo imutável do texto constitucional, sob pena de descaracterização desse conteúdo.

97 Essa possiblidade de controle, que, diga-se, não tem previsão constitucional, foi apresentada em precedente relatado pelo Ministro Moreira Alves (MS 20.257, DJ de 27 de fevereiro de 1981) e foi posteriormente restringida em julgamento que teve o Ministro Teori Zavascki como relator (MS 32.033, julgamento em 20 de junho de 2013). 
internacionais, é necessário admitir que o poder executivo também é competente para o exercício do controle de convencionalidade. ${ }^{98}$ Essa questão é mais tormentosa do que parece. Não só porque a declaração de invalidade de um ato normativo contém uma potencial agressão à instância competente para a elaboração de textos legais, competência que pode ser facilmente manipulada por dirigentes populistas, mas também porque a declaração de invalidade infundada de uma lei pode gerar a consequências graves para o detentor de um mandato presidencial, que podem constituir até mesmo em seu afastamento ou impedimento, ${ }^{99}$ é temerário impor aos chefes do poder executivo a obrigação de declarar a inconvencionalidade de leis ou atos normativos. Mais uma vez, sob o ângulo normativo, é preciso relembrar que a competência de controle não decorre pura e simplesmente da verificação da incompatibilidade de uma norma em relação a um parâmetro de validação. Ao contrário, sempre é preciso a autorização normativa para o exercício dessa competência de controle. No direito brasileiro não existe norma que autorize os órgãos integrantes da administração pública a exercer o controle de constitucionalidade. ${ }^{100}$ Dessa forma, é em regra inviável a declaração de constitucionalidade por órgãos que integrem o poder executivo. ${ }^{101} \mathrm{E}$, pelas mesmas razões, é inviável o controle de convencionalidade por esses órgãos.

Tudo somado, isso quer dizer que, ao menos no direito brasileiro, o controle de convencionalidade é uma técnica, no mínimo, desnecessária. Quando se trata, afinal, do controle de afrontas normativas a dispositivos inseridos em tratados de direitos humanos com nível constitucional, a técnica a ser empregada será o controle de constitucionalidade, conclusão que deriva imediatamente do dispositivo constitucional que equipara a eficácia dessas normas às emendas constitucionais. De outro lado, quando se está perante uma afronta de um parâmetro inserido em um tratado infraconstitucional, mas supralegal, o caso não envolverá a invalidação de qualquer norma, o que afasta essa técnica não só do conceito, mas também dos procedimentos de controle. Em meio a essa confusão procedimental, quem perde é o cidadão, que só quer que seus direitos humanos e fundamentais sejam respeitados.

98 Foi o que afirmou a Corte interamericana de forma explícita na Sentença do caso Gelman vs. Uruguai, de 24 de fevereiro de 2011, parágrafo 193

99 Ao negar vigência a leis, o chefe do poder executivo está sujeito à intervenção federal (art. 34, VI, CF/1988) ou à sua responsabilização em processo político administrativo conduzido perante o Congresso nacional (art. 84, II, CF/1988).

100 Nesse sentido e listando os precedentes brasileiros, muitas vezes contraditórios, a esse respeito, ver: LAURENTIIS, Lucas Catib de. Entre lei e constituição: a administração pública e o controle de constitucionalidade no direito brasileiro. RDA - Revista de Direito Administrativo, vol. 260, p. 133-166, maio/ago. 2012.

101 Na jurisprudência constitucional e nesse sentido, afirmando que órgãos administrativos, inclusive ConseIhos nacionais, não têm competência de controle: MS 32.582, rel. min. Celso de Mello, j. de 24 de fevereiro de 2014; MS 28.872 AgR, rel. min. Ricardo Lewandowski, j. 18 de março de 2011. Mais recentemente, o Supremo Tribunal Federal admitiu, porém, que, uma vez firmada uma tese com repercussão geral, os órgãos administrativos passam a ter competência para declarar a invalidade de normas que afrontem o entendimento vinculante do judiciário, o que não afasta a regra geral: Pet. 4.656, rel. min. Carmen Lúcia, j. de 12 de dezembro de 2016. 


\section{CONCLUSÕES}

Controle é interpretação e interpretar é uma atividade humana. Disso resultam as principais conclusões desse trabalho. Primeiro, mais do que uma técnica jurídica, o controle é um instrumento político que transfere a competência decisória, antes concentrada em instâncias eleitas pela via democrática. Esse movimento não é, nem pode ser, de soma zero, o que quer dizer que ao criar o controle de convencionalidade, a CIDH está retirando a competência e a possibilidade de escolha de outros órgãos e outras instâncias. Quanto a isso, essa Corte adotou uma compreensão radical, segundo a qual o poder judiciário deve levar em conta não apenas o tratado, mas também a interpretação da $\mathrm{CIDH}$, que é a intérprete última da Convenção americana. ${ }^{102}$

Essa é uma opção radical porque retira dos Estados, incluído aí os juízes e cidadãos, qualquer margem de apreciação e opção interpretativa. Tudo ocorre como se a $\mathrm{CIDH}$ fosse a dona definitiva e absoluta da verdade sobre as questões controversas e polêmicas tratadas em sua jurisprudência. Por outro lado, tudo se passa como se os integrantes dessa Corte e os defensores do controle de convencionalidade considerassem todos os demais órgãos estatais e judiciais integrantes do continente latino-americano como incapazes de oferecer uma resposta tão convincente quanto a apresentada pelos deuses-juízes de São José da Costa Rica. Sob essa ótica, o controle de convencionalidade não é só um instrumento confuso e sem fundamentação técnica; é também uma prática elitista, que pressupõe a incapacidade ou a má-fé de todo aquele que ouse discordar ou questionar uma conclusão da CIDH.

A convencionalidade é, dessa forma, um conceito antidemocrático. Nela estão concentrados os grandes males da cultura jurídica latino-americana: a inconsistência prática e teórica de seus pressupostos, a incoerência da técnica, enfim, a falta de previsibilidade de seus resultados. Sobretudo, há nesse conceito o ar das promessas salvacionistas que há tempos habitam a política latino-americana e hoje se tornaram uma característica mundial: a convencionalidade foi apresentada como o remédio e a chave para a solução de todos os males. Disso decorrem duas consequências perversas. A primeira é a infantilização dos cidadãos, que não são mais tratados como atores morais dignos de confiança em suas escolhas e devem aceitar, sem questionar, as consequências apresentadas pela CIDH. No tema da justiça de transição, que envolve a possibilidade de responsabilização pela prática de graves crimes cometidos durante a vigência de ditaduras, essa consequência se apresenta com particular eloquência, pois aqui a CIDH sugere que o único meio de superar o passado antidemocrático é perseguir e prender todo aquele que tenha um dia ousado desrespeitar os parâmetros internacionais de proteção dos direitos humanos. Essa conclusão é problemática sob vários aspectos. Ela se apresenta como o único caminho para a realização da justiça

102 Caso Almonacid Arrellano e outros v. Chile, sentença de 26 de setembro de 2006, parágrafo 124. 
de transição, desconsiderando as experiências internacionais que adotaram caminhos alternativos - a África do Sul, por exemplo. Pressupõe, fora isso, que o combate a graves crimes do passado deve ocorrer de qualquer forma e qualquer custo, mesmo que o resultado disso seja a quebra e o desrespeito de regras elementares do direito, dentre elas a não retroatividade das leis e a prescrição de crimes. ${ }^{103}$

Enfim, ao defender e impor o seu ponto de vista a qualquer custo e qualquer preço, a CIDH radicaliza o debate jurídico, pois trata seus críticos como opositores e os réus como inimigos. Aqueles devem ser silenciados; estes, perseguidos. A proposta da CIDH se revela, assim, como uma espécie de democracia militante, que aplica táticas e conclusões antidemocráticas contra antidemocratas. Tudo com o fim último e belo de defender a democracia imaginada pelos juízes de São José da Costa Rica. Uma democracia peculiar, na qual cidadãos mudos e subservientes ouvem, sem contestar, as conclusões da CIDH e as repetem à exaustão, para que os críticos infiéis se acostumem com essas verdades eternas. Um modelo que aceita qualquer caminho, forma ou instrumento, mesmo os mais incompreensíveis e polêmicos - a convencionalidade, por exemplo - desde que o fim último e ideal perseguido pelos integrantes daquele tribunal seja alcançado.

Esse é um sistema democrático de ataque, em que a dissidência é tratada como resistência e a discussão é vista como insubordinação. Uma forma de governo de juízes radical, que veste suas compreensões políticas e suas visões de mundo com o manto de palavras sonoras e mágicas, para com isso impor suas conclusões e compreensões. Uma visão do mundo que combate o erro e a oposição de forma radical e intolerante, pois seus defensores partem do princípio de que a intolerância dos opositores deve, se preciso, ser combatida com mais intolerância. Ao fechar todas as portas do dissenso e discordância, ao exigir que pessoas autoridades e tribunais apliquem de forma cega e automática suas interpretações, enfim, ao calar o debate e silenciar as vozes discordantes, a CIDH adota essa compreensão radical de democracia.

O controle de convencionalidade é a figura retórica de feições técnicas que serve a esse objetivo. Mais do que um instrumento de controle, ele é uma forma de se realizar uma política expansionista de ocupação de espaços decisórios deixados vagos pelos perpétuos conflitos políticos regionais. Mesmo que a intensão original da CIDH tenha sido pacificar esses conflitos, ${ }^{104}$ os efeitos práticos dessa atuação foram nulos - as democracias e a proteção dos direitos humanos na região continuam sob forte ameaça

\footnotetext{
103 Uma análise bastante completa desses casos, bem como precisas conclusões críticas sobre os problemas desse ativismo operacionalizado pela Corte, é feita por: MALARINO, Ezequiel. Judicial Activism, Punitivism and Supranationalisation: Illiberal and Antidemocratic Tendencies of the Inter-American Court of Human Rights. International Criminal Law Review, [s.I.], vol. 12, p. 665-695, 2012.

104 Nesse sentido, afirmando que a CIDH foi levada a adotar uma postura ativista para combater os constants desmandos de ditaduras latino-americanas: CONTESSE, Jorge. The Final Word? Constitutional Dialogue and the Inter-American Court of Human Rights, I-CON, [s.I.], vol. 15, n. 2, p. 414-435, 2017.
} 
- ou contraproducentes - a radicalização do ponto de vista da CIDH tem como resposta a radicalização do ponto de vista contrário. Frente ao avanço do radicalismo ideológico na região e tendo em conta as dificuldades teóricas e práticas enfrentadas pela CIDH, talvez seja melhor dar um passo atrás, rever conceitos e fazer um exercício de autocrítica. Afinal, a democracia e a cidadania nunca são realizadas de uma vez por todas e, por isso mesmo, todo aquele que apresente uma solução mágica e simples para os problemas complexos da convivência humana tem grandes chances de ser o populista que utiliza palavras democráticas para atingir fins não democráticos. Não há nada de essencialmente errado na revisão de posições, decisões ou jurisprudências conceitualmente problemáticas. A democracia é construída por tentativas e erros, por pessoas de carne e osso falíveis e imperfeitas e, por isso, a virtude democrática está naquele que tem a humildade de propor soluções e avaliar criticamente os resultados dessas propostas. ${ }^{105}$

Essa é a posição em que se encontra a $\mathrm{CIDH}$, um tribunal internacional novo e inserido em um ambiente de efervescência cultural, política e ideológica. Uma corte que trabalha com recursos financeiros e humanos escassos e que é confrontada com os mais diversos dilemas morais. Lançada nesse caldo cultural multiétnico, a proposta inicial da CIDH foi ousar, não só por adotar compreensões inovadoras a respeito da forma de proteção dos direitos humanos em específico, mas também por ter criado instrumentos de controle especificamente destinados a resguardar a autoridade de suas decisões. O controle de convencionalidade serve a esse fim. Chegou a hora de realizar essa avaliação crítica e enfrentar as questões essenciais, que não podem ser contornadas: qual é o balanço teórico e prático da aplicação dessa técnica? No que ela contribuiu para a defesa dos direitos humanos na américa-latina? Enfim, qual foi o ganho democrático por ele gerado? Sem apresentar respostas convincentes a essas questões, o controle de convencionalidade não tem razões nem fundamentos para existir. E essa é, na verdade, a principal conclusão e a proposta deste trabalho acadêmico: elimine-se, ao menos enquanto não são encontradas explicações mais convincentes para o seu funcionamento, o controle de convencionalidade. Isso não quer dizer que os direitos humanos na região ficarão desprotegidos, pois a CIDH e a Comissão interamericana dispõem de uma série de outros instrumentos - dentre eles os relatórios periódicos e a responsabilização internacional política e pecuniária dos Estados faltosos - que podem e devem ser aplicados em casos de violação de normas de proteção de direitos humanos e fundamentais. Por outro lado, essa mudança de rumos eliminaria o emaranhado de debates e paradoxos em que se transformou o controle de convencionalidade e faria com que os estudiosos voltassem a se concentrar no que tem de mais essencial nessa matéria: qual é o conteúdo dos direitos? Por muito tempo essa pergunta simples ficou

105 Para uma análise mais aprofundada desses aspectos, ver: FERREIRA, Felipe Grizotto; CABRAL, Guilherme Perez; FERREIRA, Felipe Grizotto; CABRAL, Guilherme Perez; LAURENTIIS, Lucas Catib de. O exercício da jurisdição interamericana de direitos humanos: legitimidade, problemas e possíveis soluções. Revista de Direito Internacional, [s.I.], vol. 16, n. 2, p. 243-268, 2019. 
à sombra do protagonismo da noção de controle de convencionalidade. Chegou a hora de voltar a ela e também de eliminar de uma vez por todas os problemas, debates e crises gerados pelo controle de convencionalidade. Os direitos humanos e a democracia regional agradecem e muito.

\section{REFERÊNCIAS}

ALCALÁ, Humberto Nogueira. Los desafíos del control de convencionalidad del corpus iuris interamericano para los trinunales nacionales y su diferenciación con el control de constitucionalidad. In: MARINONI, Luiz Guilherme; MAZZUOLI, Valério de Oliveira (Coord.). Controle de convencionalidade: um panorama latino-americano. Brasília: Gazeta Jurídica, 2013.

ALCALÁ, Humberto Nogueira. Reforma constitucional de 2005 y control de constitucionalidade de tratados internacionales. Estudios Constitucionales, Talca, vol. 5, n. 1, 59-88, 2007.

ALIANAK, Rachel Cynthia. El renovado derecho administrativo a la luz del control de convencionalidad. Revista latinoamericana de derecho administrativo, [s.I.], vol. 2, n. 1, p. 283-299, 2015. ALMEIDA, Fernanda Dias Menezes de. Competências na Constituição de 1988. 4. ed. São Paulo: Atlas, 2007.

ALMEIDA, Fernanda Dias Menezes de. A incorporação dos tratados internacionais ao ordenamento jurídico brasileiro: análise do tema à luz do direito constitucional. Revista do Advogado, São Paulo, ano 23, n. 73, p. 48-58, 2003.

ANDO, Nisuke. National implementation and interpretation. In: SHELTON, Dinah (Org.). The Oxford Handbook of International Human Rights Law, Oxford: Oxford University Press, 2013.

BOGDANDY, Armin von. Demokratie, Globalisierung, Zukunft des Völkerrechtes - eine Bestandaufnahme. ZaöRV, [s.I.], vol. 63, p. 853-877, 2003.

BARAK, Ahron. The judge in a Democracy. Princeton and Oxford: Princeton University Press, 2006.

BARROSO, Luís Roberto. Contramajoritário, representativo e iluminista: os papeis dos tribunais constitucionais nas democracias contemporâneas. Direito e Praxis, Rio de Janeiro, vol. 9, n. 4, p. 2171-2228, 2018.

BAZÁN, Victor. El control de convencionalidade: incógnitas, desafios y perspectiva. In: BAZÁN, Victor, NASH, Claudio (Org.). Justicia constitucional y derechos fundamentales: el control de convencionalidad, Berlim: Konrad Adenauer Stiftung, 2011.

BAZÁN, Victor. O controle de convencionalidade e a necessidade de intensificar um adequado diálogo jurisprudencial. Revista direito público, vol. 8, n. 41, p. 218-235, set./out. 2011. 
BELTRAMELLI NETO, Silvio; KLUGE, Cesar Henrique. Controle de convencionalidade difuso e concentrado em matéria trabalhista nas perspectivas da OIT e do Sistema interamericano de proteção dos direitos humanos. Revista direito e justiça - reflexões sóciojurídicas, Santo Ângelo, ano XVII, n. 28, p. 105-123, 2017.

BILDER, Christina. The prohibition of amnesties by the inter-American Court of Human Rights, German law journal, [s.I.], vol. 12, n. 5, p. 1203-1230, 2011.

BURGORGUE-LARSEN, Laurence. Chronicle of a Fashionable Theory in Latin America: Decoding the Doctrinal Discourse on Conventionality Control. In: HAECK Yves; HERRERA, Clara Burbano; CHIRIBOGA, Oswaldo Ruiz (Org.). The Inter-American Court of Human Rights: Theory and Practice, Present and future, Cambridge: Intersentia, 2016.

CAMILO, Guilherme Vitor de Gonzaga. A aplicação dos tratados e a doutrina do controle de convencionalidade: bases jurídicas e efetivação. Revista de direito brasileira, São Paulo, vol. 17, n. 7, p. 18-39, maio/ago. 2017.

CAMPOS, Bárbara Pincowsca Cardoso. Controle de convencionalidade: aproximação entre direito internacional e constitucionalismo?. Revista do instituto brasileiro de direitos humanos, [s.l.], vol. 13, n. 13, p. 47-58, 2013.

CARNEIRO, Athos Gusmão. Jurisdição e competência. São Paulo: Revista dos Tribunais, 2005.

CARVALHO, Alexander Perazo Nunes de. Convencionalização do direito civil: a aplicação dos tratados e convenções internacionais no âmbito das relações privadas. Revista de direito internacional, Brasília, vol. 12, n. 2, p. 341-354, 2015.

CANOTILHO, J.J. Gomes. Direito Constitucional e Teoria da Constituição. 3. ed. Coimbra: Almedina, 1998.

CAVALLO, Gonzalo Aguilar. El control de convencionalidad: análisis en derecho comparado. Revista Direito GV, São Paulo, n. 18, p. 721-754, jul./dez. 2013.

CHAVES, Denilsson Gonçalves; SOUSA, Mônica Teresa Costa. O controle de convencionalidade e a autoanálise do poder judiciário brasileiro. Revista da Faculdade de Direito - UFPR, Curitiba, vol. 61, n. 1, p. 87-113, jan./abr. 2016.

CLÈVE, Clèmerson Merlin. A fiscalização abstrata de constitucionalidade no direito brasileiro. São Paulo: Revista dos Tribunais, 1995.

CONCl, Luiz Guilherme Arcaro. O controle de convencionalidade como parte de um constitucionalismo transnacional fundado na pessoa humana. Revista de processo, São Paulo, vol. 39, n. 232, p. 363-390, jun. 2014.

CONTESSE, Jorge. The Final Word? Constitutional Dialogue and the Inter-American Court of Human Rights. I-CON, [s.I.], vol. 15, n. 2, p. 414-435, 2017. 
CONTRERAS, Pablo. National discretion and international deference in the restriction of human rights: a comparation between the jurisprudence of the European and inter-american Court of human rights. Northwestern journal of international human rights, [s.l.], vol. 11, n. 28, p. 28-82, 2012.

DAHL, Robert. Tomada de decisão na democracia - a Suprema Corte como instituição nacional de tomada de decisão política. In: MENDES, Gilmar Ferreira; GALVÃO, Jorge Octávio Lavocat; MUDROVITSCH, Rodrigo Bittencourt (Org.). Jurisdição constitucional em 2020. São Paulo: Saraiva, 2016.

DIMOULIS, Dimitri; LUNARDI, Soraya. Curso de processo constitucional. São Paulo: Atlas, 2013.

DINAMARCO, Cândido Rangel. Instituições de processo civil: volume 1. 5. ed. São Paulo: Malheiros, 2005.

DINH, Nguyen Quoc; DAILLIER, Patrick; PELLET, Alain. Direito internacional público. Lisboa: Calouste Gulbenkian, 2003.

DRAGO, Guillaume. Contentieux constitutionnel français. 3. ed. Paris: PUF.

DULITZKY, Ariel. An Inter-American Constitutional Court? The Invention of the Conventionality Control by the Inter-American Court of Human Rights. Texas International Law Journal, Texas, vol. 50, n. 1, p. 47-93, 2015.

DULITZKY, Ariel. La aplicación de los tratados de derechos humanos por los tribunales locales: un estudio comparado. In: ABREGÚ, Martin; COURTIS, Christian (Org.). La aplicación de los tratados sobre derechos humanos por los tribunales locales, Argentina: Ed. del Puerto, 1997.

FABBRINI, Federico. Kelsen in Paris: France's Constitutional Reform and the introduction of a posteriori constitutional review of legislation. German Law Journal, [s.l.] vol. 9, n. 10, p. 1297- 1312, 2008.

FEITOSA, Gustavo Raposo; SILVA NETO, Ademar Monteiro. Audiência de custódia, convenções internacionais de direitos humanos e liberdade de locomoção. NOMOS - Revista do Programa de Pós-Graduação em Direito da UFC, Fortaleza, vol. 36, n. 2, p. 153-170, 2016.

FERREIRA, Marcelo Ramos Peregrino. $\mathbf{O}$ controle de convencionalidade da Lei da Ficha Limpa: direitos políticos e inelegibilidades, Rio de Janeiro: Lumen Juris, 2015.

FERREIRA, Felipe Grizotto; CABRAL, Guilherme Perez; LAURENTIIS, Lucas Catib de. O exercício da jurisdição interamericana de direitos humanos: legitimidade, problemas e possíveis soluções. Revista de Direito Internacional, [s.I.], vol. 16, n. 2, p. 243-268, 2019.

GARCIA RAMIREZ, Sergio. El control judicial interno de convencionalidad. Revista IUS, Puebla, vol. 5, n. 28, p. 123-159, 2011.

GOMES, Eduardo Bianchi. Controle de convencionalidade nos processos de integração - Democracia e Mercosul (a construção de uma tese). A\&C - Revista de Direito Administrativo e Constitucional, Belo Horizonte, ano 13, n. 52, p. 231-245, 2013. 
GOMES, Eduardo Bianchi; GONÇALVES, Ane Elise. O controle de convencionalidade, a Convenção Americana de Direitos Humanos e o crime de desacato. Revista Jurídica da Presidência, [s.l.], vol. 18, n. 114, p. 73-96.

HENNEBEL, Ludovic. The Inter-American Court of Human Rights: the Ambassador of Universalism. Quebec Journal of International Law, Quebec, n. 57, special edition, p. 57-97, 2011.

HITTERS, Juan Carlos. Control de constitucionalidad y control de convencionalidad: comparación. Estudios Constitucionales, Talca, vol. 7, n. 2, p. 109-128, 2009.

KELSEN, Hans. Jurisdição constitucional. São Paulo: Martins Fontes, 2003.

KELSEN, Hans. O problema da justiça. São Paulo: Martins Fontes, 1998.

KELSEN, Hans. Principles of International Law. New York: Rinehart and Co., 1952.

KELSEN, Hans. Teoria pura do direito. 6. ed. São Paulo: Martins Fontes, 1988.

KOSKENNIEMI, Martti. International Law as Political Theology: How to Read Nomos der Erde?. Constellation, [s.l.], vol. 11, n. 4, p. 492-511, 2004.

JUÁREZ, Karlos A. Castilla. Control de convencionalidade interamericano: una mera aplicación del derecho internacional. Revista Derecho del Estado, n. 33, p. 149-172, jul./dez. 2014.

LAURENTIIS, Lucas Catib de. A proporcionalidade no direito constitucional: origem, modelos e reconstrução dogmática. São Paulo: Malheiros, 2017.

LAURENTIIS, Lucas Catib de. Muito barulho pra nada: problemas do procedimento de recepção dos tratados de direitos humanos com hierarquia constitucional. In: LISBOA, Marcos José Alves; GASPAR, Renata Alvares (Org.). Direito globalizado, ética e cidadania. Belo Horizonte: Arraes editores, 2017.

LAURENTIIS, Lucas Catib de. Entre lei e constituição: a administração pública e o controle de constitucionalidade no direito brasileiro. RDA - Revista de Direito Administrativo, Rio de Janeiro, vol. 260, p. 133-166, maio/ago. 2012.

LAURENTIIS, Lucas De; GALKOWICZ, Henrique. Medidas cautelares interpretativas e de efeito aditivos no controle de constitucionalidade: uma análise crítica de sua aplicação. Revista Direito GV, São Paulo, n. 21, p. 65-88, 2015.

MAC-GREGOR, Eduardo Ferrer. Interpretación conforme y control difuso de convencionalidad: el nuevo paradigma para el juez mexicano. Estudios Constitucionales, Talca, vol. 9, n. 2, p. 531-622, 2011.

LÜBBE-WOLFF, Gertrude. ECtHR and national jurisdiction - The Görgülü Case. Humboldt Forum Recht, n. 12, p. 138-146, 2006. 
MAGALHÃES, Breno B. O controle difuso de convencionalidade no Brasil: soluções para seu aprimoramento. In: CHAl, Cássius Guimarães; BUSSINGUER, Elda Coelho de Azevedo; CHAVES, Valena Jacob (Org.). Ensaios críticos: do político ao jurídico. 1. ed. Campos dos Goytacazes: Brasil Multicultural, 2016.

MALARINO, Ezequiel. Judicial Activism, Punitivism and Supranationalisation: Illiberal and Antidemocratic Tendencies of the Inter-American Court of Human Rights. International Criminal Law Review, [s.I.], vol. 12, p. 665-695, 2012.

MANCUSO, Rodolfo de Camargo. Recurso extraordinário e recurso especial. 10. ed. São Paulo: Revista dos Tribunais, 2007.

MARINONI, Luiz Guilherme. Controle de convencionalidade (na perspectiva do direito brasileiro). In: MARINONI, Luiz Guilherme; MAZZUOLI, Valério de Oliveira (Coord.). Controle de convencionalidade: um panorama latino-americano. Brasília: Gazeta Jurídica, 2013.

MARTINS, Leonardo. Proporcionalidade como critério de controle de constitucionalidade: problemas de sua recepção pelo direito e jurisdição constitucional brasileiros. Cadernos de Direito, Piracicaba, n. 3 (5), p. 15-45, jul./dez. 2003.

MARTINS, Leonardo; MOREIRA, Thiago Oliveira. Constitucionalidade e Convencionalidade de Atos do Poder Público: concorrência ou hierarquia? Um contributo em face da situação jurídico-constitucional brasileira. Anuario de Derecho Constitucional Latino Americano, [s.l.], vol. 17, p. 463483, 2011.

MARTINS, Leonardo; MOREIRA, Thiago Oliveira. Controle de convencionalidade de atos do poder público - concorrência ou hierarquia em face do controle de constitucionalidade?. In: PAGLIARINI, Alexandre Coutinho; DIMOULIS, Dimitri (Coord.). Direito constitucional internacional dos direitos humanos. Belo Horizonte: Fórum, 2012.

MAZZUOLI, Valério de Oliveira. Hierarquia constitucional e incorporação automática dos tratados internacionais de proteção dos direitos humanos no ordenamento brasileiro. Revista de informação legislativa, [s.l.], ano 37, n. 138, p. 231- 250, out./dez., 2000.

MAZZUOLI, Valério de Oliveira. $\mathbf{O}$ controle jurisdicional da convencionalidade das leis. 2. ed. São Paulo: Revista dos Tribunais, 2011.

MELLO, Celso D. de Albuquerque. Curso de direito internacional público. 15. ed. Rio de Janeiro: Renovar, 2004.

MIRANDA, Jorge. Manual de direito constitucional: inconstitucionalidade e garantia da constituição. 3. ed. Coimbra: Coimbra Editora, 2008.

MONTEIRO, Marco Antonio Corrêa. Tratados internacionais de direitos humanos e direito interno. São Paulo: Saraiva, 2011. 
MOREIRA. O Exercício do Controle de Convencionalidade pela Corte Interamericana de Direitos Humanos: Uma Década de Decisões Assimétricas. In. MENEZES, Wagner (Org.). Direito Internacional em Expansão. Anais do XV CBDI. Belo Horizonte: Arraes Editores, 2017, p. 251- 271.

MÜCKL, Stefan. Kooperation oder Konfrontation? Das Verhältnis zwischen Bundesverfassungsgericht und Europäischem Gerichtshot für Menchenrechte. Der Staat, [s.I.], vol. 44, n. 3, p. 403-431, 2005.

MURSWIEK, Dietrich. Souveränität und Humanitäre intervention. Der Staat, [s.l.], vol. 35, n. 1, p. 31-44, 1996.

NEUMAN, Gerald L. Import, Export, and Regional Consent in the Inter-American Court of Human Rights. The European Journal of International Law, [s.I.], vol.19, n. 1, p. 101-123, 2008.

PIOVESAN, Flávia. Direitos humanos e diálogo entre jurisdições. Revista Brasileira de Estudos Constitucionais, São Paulo, n. 19, p. 67-93, 2012.

PIOVESAN, Flávia. Direitos humanos e o Direito constitucional internacional. São Paulo: Saraiva, 2008.

POSNER, Richard. Enlightened Despot, The New Republic, [s.I.], [s.n.], 23 de abril, 2007.

POTACS, Michael. Das Verhältnis zwischen der EU und ihren Mitgliedstaaten im Lichte traditioneller Modelle. ZöR, [s.I.], n. 65, 117-139, 2010.

RAMÍREZ, Sergio Garcia. El control judicial interno de convencionalidad. In: MAC-GREGOR, Eduardo Ferrer (Coord.). El control difuso de convencionalidad: Diálogo entre la Corte Interamericana de Derechos Humanos y los jueces nacionales. México: Fundap, 2012.

RAMOS, André Carvalho. Curso de direitos humanos. 4. ed. São Paulo: Saraiva, 2017.

RAMOS, André Carvalho. Responsabilidade internacional do Estado por violações de direitos humanos. Revista CEJ, Brasília, n. 29, p. 53-63, abr./jun. 2005.

RAMOS, André Carvalho. Supremo Tribunal Federal brasileiro e o controle de convencionalidade: levando a sério os tratados de direitos humanos. Revista da Faculdade de Direito da Universidade de São Paulo, São Paulo, vol. 104, p. 241-286, jan./dez. 2009.

RAMOS, Elival da Silva. A inconstitucionalidade das leis: vício e sanção. São Paulo: Saraiva, 1994.

RAMOS, Elival da Silva. Controle de constitucionalidade no Brasil: perspectivas de evolução, São Paulo: Saraiva, 2010.

REIMER, Philipp. "L'état, c'est le droit" - sobre a atualidade da teoria do Estado de Hans Kelsen em face da metamorfose do poder estatal. Cadernos do programa de pós-graduação em Direito UFRGS, Porto alegre, vol. XI, n. 1, p. 50-79, 2016. 
ROCHA, Matheus Lins; FERREIRA, Olavo A.; TARREGA, Maria Cristina. O controle de convencionalidade difuso de ofício e a vedação das decisões-surpresa. Espaço Jurídico Journal of Law, Joaçaba, vol. 20, n. 2, p. 317-336, jul./dez. 2019.

ROTHENBURG, Walter Claudius. Constitucionalidade e convencionalidade da Lei de Anistia Brasileira. Revista de Direito GV, São Paulo, vol. 9, n. 2, p. 681-705, 2016.

RUSSOWSKY, Iris Saraiva. O controle de convencionalidade das leis: uma análise na esfera internacional e interna. Revista CAAP, Belo Horizonte, vol. XVIII, n. 2, p. 61-96, 2012.

SAGÜÉS, Nestor Pedro. Obrigaciones internacionales y control de convencionalidade. Estudios Constitucionales, Talca, vol. 8, n. 1, p. 117-136, 2010.

SCHMITT, Carl. Teologia política. Belo Horizonte: Del Rey, 2006.

SEGADO, Francisco Fernández. La Jurisdiccion Constitucional Ante El Siglo XXI, la quiebra de la bipolaridad sistema americano-sistema europeo-kelseniano y la búsqueda de nuevas variables explicativas de los sistemas control de constitucionalidad. ANALES de la Academia Nacional de Derecho y Ciencias Sociales de Córdova, Córdoba, Tomo XLI, p. 35-81, 2002.

SILVA, José Afonso. Um pouco de direito constitucional comparado. São Paulo: Malheiros, 2009. SLAUGHTER, Anne-Marie. A Global Community of Courts. Harvard International Law Journal, Cambridge, vol. 44, p. 191-219, 2003.

SULTANY, Nimer. The legacy of justice Aharon Barak: a critical review. Harvard International Law Journal, Cambridge, vol. 48, p. 83-92, 2007.

TALAMINI, Eduardo. O exame de sentenças da jurisdição brasileira pela Corte Interamericana de Direitos Humanos. Cadernos da Escola de Direito e Relações Internacionais da Unibrasil, [s.l.], vol. 06, p. 205-229, 2006.

TORRIJO, Ximena Fuentes. International and Domestic Law: Definitely an Odd Couple. University of Puerto Rico Law Review-Seminar in Latin America on Constitutional and Political Theory (SELA), [s.I.], vol. 77, n. 2, p. 483-505, 2008.

TUSHNET, Mark. The inevitable globalization of Constitutional Law. Virginia Journal of International Law, [s.l.], vol. 50, p. 985-1004, 2009.

VERDROSS, Alfred. Völkerrecht. 3. ed. Wien: Springer, 1955.

VIEIRA, Oscar Vilhena. A constituição e sua reserva de justiça. São Paulo: Malheiros, 1999. 